\title{
Mammalian bone palaeohistology: a survey and new data with emphasis on island forms
}

Christian Kolb, Torsten M. Scheyer, Kristof Veitschegger, Analia M. Forasiepi, Eli Amson, Alexandra A E van der Geer, Lars W. van den Hoek Ostende, Shoji Hayashi, Marcelo R. Sánchez-Villagra

The interest in mammalian palaeohistology has increased dramatically in the last two decades. Starting in 1849 via descriptive approaches, it has been demonstrated that bone tissue and vascularisation types correlate with several biological variables such as ontogenetic stage, growth rate, and ecology. Mammalian bone displays a large variety of bone tissues and vascularisation patterns reaching from lamellar or parallel-fibred to fibrolamellar or woven-fibred bone, depending on taxon and individual age. Here we systematically review the knowledge and methods on cynodont and mammalian bone microstructure as well as palaeohistology and discuss potential future research fields and techniques. We present new data on the bone microstructure of two extant marsupial species and of several extinct continental and island placental mammals. Extant marsupials display mainly parallel-fibred primary bone with radial and oblique but mainly longitudinal vascular canals. Three juvenile specimens of the dwarf island hippopotamid Hippopotamus minor from the Late Pleistocene of Cyprus show reticular to plexiform fibrolamellar bone. The island murid Mikrotia magna from the Late Miocene of Gargano, Italy displays parallel-fibred primary bone with reticular vascularisation and strong remodelling in the middle part of the cortex. Leithia sp., the dormouse from the Pleistocene of Sicily, is characterised by a primary bone cortex consisting of lamellar bone and a high amount of compact coarse cancellous bone. The bone cortex of the fossil continental lagomorph Prolagus oeningensis and three fossil species of insular Prolagus displays mainly parallel-fibred primary bone and reticular, radial as well as longitudinal vascularisation. Typical for large mammals, secondary bone in the giant rhinocerotoid Paraceratherium sp. from the Late Oligocene of Turkey is represented by dense Haversian bone. The skeletochronological features of Sinomegaceros yabei, a large-sized deer from the Pleistocene of Japan closely related to Megaloceros, indicate a high growth rate. These examples and the synthesis of existing data show the potential of bone microstructure to reveal essential information on life history evolution. The bone tissue and the skeletochronological data of the sampled island species suggest the presence of various modes of bone histological modification and mammalian life history evolution on islands to depend on factors of island evolution such as island size, distance from mainland, climate, 
phylogeny, and time of evolution. 
1 Mammalian bone palaeohistology: a survey and new data with emphasis on island forms

2 Christian Kolb $^{1 *}$, Torsten M. Scheyer ${ }^{1}$, Kristof Veitschegger ${ }^{1}$, Analia M. Forasiepi ${ }^{2}$, Eli Amson ${ }^{1}$, 3 Alexandra van der Geer ${ }^{3}$, Lars W. van den Hoek Ostende ${ }^{3}$,Shoji Hayashi ${ }^{4}$, Marcelo R. Sánchez$4 \quad$ Villagra $^{1}$

5

6 'Paläontologisches Institut und Museum der Universität Zürich, Karl Schmid-Strasse 4, CH-

78006 Zürich, Switzerland (christian.kolb@pim.uzh.ch, Tel. +41(0)446342269;

8 tscheyer@pim.uzh.ch,Tel.: +41(0)446342322; kristof.veitschegger@pim.uzh.ch,Tel.:

9 +41(0)446342329; eli.amson@pim.uzh.ch, Tel+41(0)446342148; m.sanchez@pim.uzh.ch, Tel.

$10+41(0) 446342342)$

$12{ }^{2}$ Consejo Nacional de Investigaciones Científicas y Técnicas (CONICET), Instituto Argentino de

13 Nivología, Glaciología y Ciencias Ambientales (IANIGLA), Centro Científico y Tecnológico

14 (CCT), Av. Ruiz Leals/no 5500, Mendoza-ciudad, Mendoza, Argentina (acanthodes@gmail.com, 15 Tel. $+54(261) 5244253)$

$17{ }^{3}$ Naturalis Biodiversity Center, P.O. Box 9517, 2300 RA Leiden, The Netherlands

18 (alexandra.vandergeer@naturalis.nl,Tel.+31(0)717517390;

19 lars.vandenhoekostende@naturalis.nl, Tel. +31(0)715687685)

$21{ }^{4}$ Osaka Museum of Natural History, Nagai Park 1-23, Higashi-Sumiyoshi-Ku, Osaka, 546-0034, 22 Japan (hayashi@mus-nh.city.osaka.jp) 


5

${ }^{*}$ Corresponding author

\section{Abstract}

The interest in mammalian palaeohistology has increased dramatically in the last two decades. Starting in 1849 via descriptive approaches, it has been demonstrated that bone tissue and vascularisation types correlate with several biological variables such as ontogenetic stage, growth rate, and ecology. Mammalian bone displays a large variety of bone tissues and vascularisation patterns reaching from lamellar or parallel-fibred to fibrolamellar or wovenfibred bone, depending on taxon and individual age. Here we systematically review the knowledge and methods on cynodont and mammalian bone microstructure as well as palaeohistology and discuss potential future research fields and techniques. We present new data on the bone microstructure of two extant marsupial species and of several extinct continental and island placental mammals. Extant marsupials display mainly parallel-fibred primary bone with radial and oblique but mainly longitudinal vascular canals. Three juvenile specimens of the dwarf island hippopotamid Hippopotamus minor from the Late Pleistocene of Cyprus show reticular to plexiform fibrolamellar bone. The island murid Mikrotia magna from the Late Miocene of Gargano, Italy displays parallel-fibred primary bone with reticular vascularisation and strong remodelling in the middle part of the cortex. Leithia sp., the dormouse from the Pleistocene of Sicily, is characterised by a primary bone cortex consisting of lamellar bone and a high amount of compact coarse cancellous bone. The bone cortex of the fossil continental lagomorph Prolagus oeningensis and three fossil species of insular Prolagus displays mainly parallel-fibred primary bone and reticular, radial as well as longitudinal vascularisation. Typical for large mammals, secondary bone in the giant rhinocerotoid Paraceratherium sp. from the Late 
47 Oligocene of Turkey is represented by dense Haversian bone. The skeletochronological features

48 of Sinomegaceros yabei, a large-sized deer from the Pleistocene of Japan closely related to

49 Megaloceros, indicate a high growth rate. These examples and the synthesis of existing data

50 show the potential of bone microstructure to reveal essential information on life history

51 evolution. The bone tissue and the skeletochronological data of the sampled island species

52 suggest the presence of various modes of bone histological modification and mammalian life

53 history evolution on islands to depend on factors of island evolution such as island size, distance

54 from mainland, climate, phylogeny, and time of evolution.

55

56

57

\section{Introduction}

Histology of fossil bones (e.g. Ricqlès, 1976a; Padian, 2011) provides data to investigate life history variables such as age, sexual maturity, growth patterns, and reproductive cycles.

Research on fossil vertebrate hard tissues dates back to the $19^{\text {th }}$ century when it was recognised that bones and teeth are commonly very well preserved at the histological level (Quekett, 1849a; Quekett, 1849b). Since then, several descriptive surveys of different tetrapod taxa, including mammals, have been published (e.g. Schaffer, 1890; Enlow \& Brown, 1958; Ricqlès, 1976a;

Ricqlès, 1976b; Klevezal, 1996; Marin-Moratalla et al., 2014; Prondvai et al., 2014). The study of the microstructure of highly mineralised components such as blood vessel arrangement (de Boef \& Larsson, 2007) and tissue types in bones as well as teeth (e.g. Kolb et al., 2015) provides information on growth patterns and remodelling processes of hard tissues in extinct vertebrates (see also Scheyer, Klein \& Sander, 2010; Chinsamy-Turan, 2012a; and Padian \& Lamm, 2013 for summaries). 
Mammals are a well-known group of vertebrates with a well-documented fossil record.

However, until recent years and apart from a few seminal papers (Gross, 1934; Enlow \& Brown, 1958; Warren, 1963; Klevezal, 1996), mammalian bone histology received little attention by biologists and palaeontologists alike compared to dinosaurs and non-mammalian synapsids (e.g. Horner, Ricqlès \& Padian, 1999; Sander et al., 2004; Chinsamy-Turan, 2012a; see also Padian, 2013 for a review on Chinsamy-Turan, 2012a).

The present contribution summarises the main aspects about the current state of knowledge on mammalian palaeohistology without omitting some of the relevant nonmammalian contributions, presents new finds on several extant and extinct species from diverse clades, and discusses perspectives in this field of research. Bone histological traits of extinct island mammals sampled for the present study are described and implications for island evolution are discussed. Literature dealing with pathologies in mammalian bone is omitted since this goes beyond the scope of this synthesis.

\section{Bone tissue types}

In synapsids, three main types of bone matrix are distinguished. Woven-fibred bone shows highly disorganised collagen fibres of different sizes being loosely and randomly arranged. Parallel-fibred bone consists of tightly packed collagen fibrils arranged in parallel. Lamellar bone shows the highest spatial organisation. It consists of thin layers (lamellae) of closely packed collagen fibres. Both parallel-fibred and lamellar bone are indicative of relatively low growth rates (Francillon-Vieillot et al., 1990; Huttenlocker, Woodward \& Hall, 2013). Bromage et al. (2009) confirmed that lamellar bone is an incremental tissue, with one lamella formed in the species-specific time dependency of the formation of long-period increments 
92 (striae of Retzius) in enamel. The authors also showed a negative correlation between osteocyte

93 density in bone and body mass and thus suggested a central autonomic regulatory control

94 mechanism to the coordination of organismal life history and body mass. This demonstrates the

95 relevance of bone histology for understanding physiological mechanisms in extant and extinct

96 vertebrates.

97 A bone complex composed of a woven-fibred bone matrix in which osteonal lamellar

98 bone infills the space between woven bone and primary vascular canals, is defined as

99 fibrolamellar bone (Figs. 1B, 1C, 1E, 1F) (Ricqlès, 1974; Stein \& Prondvai, 2013) or

100 fibrolamellar complex (FLC; Ricqlès, 1975; Ricqlès et al., 1991; Margerie, Cubo \& Castanet,

101 2002, Prondvai et al., 2014). According to its vascular orientation, three main types of

102 fibrolamellar bone are distinguished: Laminar bone shows an almost uniform circumferential

103 orientation of vascular canals. In case circumferential canals are connected by radial ones

104 forming a dense anastomosing network, the pattern is called plexiform (Figs. 1B, 1C, 1E, 1F). An

105 anastomosing network showing random organisation with oblique orientations is defined as

106 reticular. Moreover, a radial arrangement of vascular canals is called radiating or radial bone

107 (Francillon-Vieillot et al., 1990; Chinsamy-Turan, 2012b; Huttenlocker, Woodward \& Hall, 108 2013).

109 Amprino identified for the first time a relationship between bone tissue type and growth

110 rate in vertebrates, what is now called “Amprino’s rule” (Amprino, 1947; see also Lee et al.,

111 2013). Stein \& Prondvai (2013) found, by investigating longitudinal thin sections of sauropod

112 long bones, that the amount of woven bone in the primary complex has been largely

113 overestimated (e.g., Klein \& Sander 2008), questioning former arguments on the biology and life

114 history of sauropod dinosaurs. Similarly, Kolb et al. (2015) showed, via longitudinal thin 
115 sections, that in the giant deer Megaloceros giganteus the amount of woven-fibred bone within

116 the fibrolamellar complex (FLC) is easily overestimated as well.

118 Growth marks and skeletochronology

119 Different types of growth marks in the bone cortex are distinguished in the

120 osteohistological literature. They are deposited cyclically, usually occurring within lamellar or

121 parallel-fibred bone. All kinds of growth marks indicate a change in growth rate or a complete

122 arrest of growth.

123 In all groups of mammals thin, semitranslucent to opaque bands, termed lines of arrested

124 growth (LAGs, see also Huttenlocker, Woodward \& Hall, 2013), occur (Morris, 1970; Frylestam

125 \& Schantz, 1977; Buffrénil, 1982; Chinsamy, Rich \& Vickers-Rich, 1998; Klevezal, 1996;

126 Castanet et al., 2004; Köhler et al., 2012). It has repeatedly been confirmed and is now widely

127 accepted that LAGs are deposited annually (e. g. Castanet \& Smirina, 1990; Buffrénil \&

128 Castanet, 2000; Castanet, 1994; Marangoni et al., 2009; Chinsamy-Turan, 2012b) and

129 independently of metabolic rate and climatic background (Köhler et al., 2012; Huttenlocker,

130 Woodward \& Hall, 2013) and therefore they can be used for age estimations, estimates of age at

131 sexual or skeletal maturity, and growth rate analysis.

132 Castanet et al. (2004) studied LAGs in long bones, mandibles, and tooth cementum (M2

133 and M3) of captive specimens of known aged mouse lemur, Microcebus murinus. The 43 male

134 and 23 female specimens sampled ranged from juveniles to 11-year-old adults, for which LAG

135 counts and ages correlated best in the tibiae. In individuals older than seven years the correlation

136 decreased, leading to an age underestimation of three to four years and demonstrating limitations

137 of skeletochronology in long bones (see also Klevezal, 1996; Castanet, 2006). Additionally, 
138 animals exposed to an artificially accelerated photoperiodic regimen (a 10-month cycle) show a

139 higher number of LAGs than animals of the same true age in which a yearly photoperiod is

140 maintained. According to that, there is strong evidence that photoperiodicity is an essential factor

141 for the deposition of LAGs rather than environmental factors (see also Woodward, Padian \&

142 Lee, 2013).

Köhler et al. (2012) additionally demonstrated that the annual formation of LAGs is

144 present throughout ruminants and that a cyclic arrest of growth in bone is mainly triggered by

145 hormonal cues rather than environmental stresses. By confirming seasonal deposition of LAGs

146 throughout ruminants, the general occurrence of LAGs in homeothermic endotherms has been

147 confirmed, precluding the use of lines of arrested growth as an indicator of ectothermy (Köhler et

148 al., 2012).

149 Different kinds of processes in the cortex potentially remove parts of the growth record

150 and may erase early LAGs. One of those processes is the substitution of primary bone tissue by

151 secondary bone tissue in areas where resorption previously occurred. Secondary bone can appear

152 as Haversian bone (Fig. 1I) consisting of clustered Haversian systems responding to damage

153 such as microcracks, or around the medullary cavity forming endosteal lamellar bone in response

154 to ontogenetic changes in bone shape, i.e. bone drift (Enlow, 1962).

155 Several approaches to retrocalculate the lost information have been attempted and there

156 are two ways of retrocalculating missing years. First, in case an appropriate ontogenetic growth

157 series sampling is not available, it is possible to perform arithmetic estimates of the missing

158 intervals, applied first for dinosaurs (e.g. Sander \& Tückmantel, 2003; Horner \& Padian, 2004;

159 Erickson et al., 2004). The second approach is the superimposition of thin sections of long bones

160 of different ontogenetic stages, again applied first for dinosaurs (e.g. Horner, Ricqlès \& Padian, 
161 2000; Bybee, Lee \& Lamm, 2006; Lee \& Werning, 2008; Erickson, 2014; see also Woodward,

162 Padian \& Lee, 2013 for more methodological details).

163 Marin-Moratalla, Jordana \& Köhler (2013) were the first to apply the superimposition

164 method to mammals using anteroposterior diameters of successive growth rings in five antelope

165 (Addax) femora of different ages. They found that the first LAG in adult specimens fits the

166 second growth cycle of juveniles, indicating that the first LAG is lost by resorption throughout

167 ontogeny This allowed estimates of age at death by counting all the rest lines in the bone cortex

168 and increasing the LAG count by one. Additionally, it was possible to estimate age at sexual

169 maturity. When an animal reaches maturity it is indicated by the deposition of a narrow layer of

170 avascular lamellar bone, called the outer circumferential layer (OCL, Ponton et al., 2004; Figs.

$1711 \mathrm{~B}, 1 \mathrm{C}$ ), and also referred to as the external fundamental system (EFS, sensu Horner, Ricqlès \&

172 Padian, 1999; see also Woodward, Padian \& Lee, 2013). Given that Cormack (1987) uses the

173 term "outer circumferential lamellae" (p. 305), we follow Ponton et al. (2004) in using the term

174 outer circumferential layer (OCL) instead of EFS. Marin-Moratalla, Jordana \& Köhler (2013)

175 and Jordana et al. (in press) interpreted the transition from the FLC to the OCL to represent

176 attainment of reproductive maturity in ruminants, since maturity estimates correlated well with

177 individual tooth eruption and wear stages, as well as life history data. Therefore, the authors

178 could show that in ruminants it is possible to determine age at reproductive maturity and death.

179 Maturity estimates based on the occurrence of the OCL in a recent study by Kolb et al. (2015) on

180 extant cervids showed bone microstructure corresponding well with the timing of the attainment 181 of skeletal maturity.

182

183 Material and methods 

bones of the following additional mammalian taxa, including several taxa of extinct insular mammals, were sampled. Characteristics of bone histology of the following taxa are either poorly or not at all documented in the literature (Table 1): The extant white-eared opossum Didelphis albiventris and the thick-tailed opossum Lutreolina crassicautada, the giant deer Megaloceros giganteus from the Late Pleistocene of Ireland, the Asian giant deer Sinomegaceros yabei from the Late Pleistocene of Japan, the extant southern pudu Pudu puda, the Cyprus dwarf hippopotamid Hippopotamus minor from the Late Pleistocene of Cyprus, the dormouse Leithia sp. from the Pleistocene of Sicily, the giant hornless rhinocerotoid Paraceratherium sp. from the Late Oligocene of Turkey, the continental pika Prolagus oeningensis from the Middle Miocene of La Grive, France, and the Sardinian pika Prolagus sardus from the Late Pleistocene. From the Late Miocene of Gargano, Italy, the following material was sampled: The galericine insectivore Deinogalerix sp., the giant murid Mikrotia magna, as well as the giant pikas Prolagus apricenicus and Prolagus imperialis. Ontogenetic stages in long bones have been determined by the state of epiphyseal fusion (Habermehl, 1985). the mid-shaft where the growth record is most complete (e.g. Sander \& Andrassy 2006; Kolb et al., 2015). A tibia of Megaloceros giganteus was also sampled by using a diamond-studded core drill, with sampled cores being subsequently processed (Sander \& Andrassy, 2006; Stein \& 
206 Phylogenies were produced using Mesquite 3.02 ${ }^{\circ}$ (Maddison \& Maddison, 2015) and redrawn

207 using Adobe Illustrator $\mathrm{CS}^{\odot}$.

208 Approval information - We thank Naturalis Biodiversity Center, Leiden, the Netherlands,

209 Loïc Costeur (Naturhistorisches Museum Basel, Switzerland), George Lyras (Museum of

210 Paleontology and Geology, University of Athens, Greece), Nigel Monaghan (National Museum

211 of Ireland, Natural History), Hiroyuki Taruno (Osaka Museum of Natural History, Japan), Frank

212 Zachos and Alexander Bibl (Naturhistorisches Museum Wien, Austria), Pierre-Olivier Antoine

213 (Institut des Sciences de l'Evolution-Montpellier, France), and Ebru Albayrak, (MTA Natural

214 History Museum, The General Directorate of Mineral Research and Exploration, Ankara,

215 Turkey) for approving sampling of specimens for histological study.

216

217 Mammalian bone histology - works before 1935

218 The initial contribution on the bone palaeohistology of mammals was performed by

219 Quekett (1849a, 1849b, 1855) as part of comprehensive studies dealing with the bone cortex of

220 not only mammals but also fish, reptiles, and birds. He described the tissue from mammalian

221 long bones including an extinct rhinocerotid and equid, the extinct giant deer Megaloceros

222 giganteus, the extinct proboscidean Mastodon, fossils of xenarthrans such as Megatherium, and

223 humans. Quekett (1849a, 1849b, 1855) described in these taxa Haversian canals, bony laminae,

224 bone-cells, and canaliculi as well as a the typical three layered composition of cranial bones, ribs,

225 and scapulae displaying a diploe structure within two thin compact layers. Later, Aeby (1878)

226 concentrated on taphonomical effects and compared bone tissue of reptiles, birds, and mammals.

227 Then, Kiprijanoff (1881) illustrated the bone cortex of the sperm whale (Physeter

228 macrocephalus) in a comparative study of fossil material from Russia. Schaffer (1890) described 
229 the bone tissue of several mammals, including sirenians from the Eocene, Oligocene, and

230 Miocene (Halitherium), a proboscidean from the Miocene (Mastodon), an undetermined fossil

231 cetacean, and artiodactyls (an undetermined artiodactyl referred to an antelope and

232 Hippopotamus, both from the Pliocene). Schaffer also investigated Artiodactyla (Sus scrofa,

233 Capreolus), Carnivora (Ursus spelaeus), Rodentia (Arvicola), as well as undetermined long and

234 skull bones, all from the Pleistocene. Foote (1911a, 1911b) examined in a comprehensive study

235 the femoral bone cortex of extant amphibians, birds, and mammals including marsupials,

236 rodents, lagomorphs, carnivorans, 'ungulates', and primates. Nopcsa and Heidsieck (1934)

237 studied reptile bones and the ribs of sirenians (Halitherium). In his comparative work, Gross

238 (1934) studied the bone cortex of the proboscidean Mammuthus.

\section{Bone histology of extinct and extant cynodont clades}

Non-mammalian cynodonts - Cynodonts represent the last major synapsid lineage to appear in Earth history with mammals as living representatives. Many articles have been published on non-mammalian cynodont histology in recent years (e.g. Ricqlès, 1969; Botha \&

244 Chinsamy 2000; Botha \& Chinsamy, 2004; Botha \& Chinsamy, 2005; Ray, Botha \& Chinsamy, 2004; Chinsamy \& Abdala, 2008; Botha-Brink, Abdala \& Chinsamy, 2012; Chinsamy-Turan, 2012b). Fibrolamellar bone is present to a varying degree in all cynodonts. Considerable variation in vascular density and orientation and the presence/absence of growth marks such as LAGs are evident. When observed within the phylogenetic context, there is an overall increase in bone deposition rate. This is indicated by an increasing prevalence of highly vascularised fibrolamellar bone in phylogenetically later cynodonts (Botha-Brink, Abdala \& Chinsamy,

251 2012). Several factors are proposed to influence the microstructure and therefore responsible for 
252 the aforementioned variability: phylogeny, biomechanics, ontogeny, body size, lifestyle

253 preferences, and environmental influences (Cubo et al., 2005; Kriloff et al., 2008; Botha-Brink,

254 Abdala \& Chinsamy, 2012). Padian (2013) emphasised that the correlation between fibrolamellar

255 bone and high growth rates, and endothermy is still valid, although fibrolamellar bone is known

256 to occur in rare cases in ectothermic reptiles such as crocodiles and turtles.

Multituberculata and early mammals - Histological studies of multituberculates (see Fig.

2 for mammalian groups discussed below) and in general stem mammals are scarce. Enlow \&

Brown (1958) described a section of a mandible from Ptilodus. Its cortex consisted of lamellar

bone with a central region of indistinct and unorganised lamellae, in which lacunae and cell

spaces as well as radial vascular canals were present. Morphological studies have suggested

different kinds of locomotion within the group (saltatorial, fossorial, scansorial, and arboreal;

Kielan-Jaworowska, Zifelli \& Luo, 2004), which might be reflected in the microstructure of the

appendicular bones. Chinsamy \& Hurum (2006) compared the bone tissue from long bones and

one rib of multituberculates and early mammals. They showed that Morganucodon and

multituberculates (Kryptobataar, Nemegtbataar) were characterised by fibrolamellar/woven-

fibred bone at early stages of ontogeny and later on by parallel-fibred or lamellar bone. Their

findings pointed towards relatively high growth rates compared to the late Mesozoic eutherians

Zalambdalestes and Barunlestes with periodic growth pauses as indicated by the occurrence of

LAGs. Comparisons of morganucodontid and early mammalian bone microstructure with that of non-mammalian cynodonts, extant monotremes, and placentals indicated significant differences in the rate of osteogenesis in the various groups. The authors concluded multituberculates and 
275 adaptive attribute prior to the $\mathrm{K}-\mathrm{Pg}$ event, but that a flexible growth strategy implying periodic

276 growth pauses of the early eutherians was more advantageous thereafter.

Monotremata - Monotremes are represented today by three genera (Ornithorynchus,

278 Tachyglossus, and Zaglossus) each with specialized skeletal morphology. Their poor fossil

279 record includes material from Australia and South America (Pascual et al., 1992; Musser and

280 Archer, 1998; Musser, 2003). Accordingly, the bone histology of monotremes has been scarcely

281 studied. Enlow and Brown (1958) were the first to describe sections of long bones and ribs of

282 Platypus and Echidna. Chinsamy \& Hurum (2006) described the femoral bone tissue of

283 Ornithorhynchus as being a mixture of woven-fibred bone with lamellar bone deposits.

284 Additionally, large parts of the compacta consisted of compacted coarse cancellous bone. The

285 type of vascularisation and the orientation of the vascular channels varied from simple blood

286 vessels with longitudinal, circular and radial orientations to primary osteons with longitudinal

287 and reticular arrangements. Only isolated secondary osteons were present.

Marsupialia - Despite marsupials being the second most diverse group of living

mammals, so far their bone histology is poorly studied. Early contributions are those of Foote

(1911a), Enlow \& Brown (1958) and Singh, Tonna \& Gandel (1974) on the marsupial Didelphis.

291 Our study of new samples of the white-eared opossum Didelphis albiventris and the latrine

292 opossum Lutreolina crassicaudata (Table 1) essentially confirms their observations.

The bone cortex of long bones from Didelphis is characterised by a compacta

surrounding the medullary cavity. The bone matrix is dominated by parallel-fibered bone (Figs.

3A-C). Towards the inner part, the amount of woven-fibered bone increases (Fig. 3C). In most

297 Brown (1958). Inner and outer circumferential layers are present. The inner circumferential layer 
298 consists of lamellar bone. The outer circumferential layer is dominated by parallel-fibered bone.

299 The thickness of this layer varies between specimens. Except in one specimen with one LAG, no

300 LAGs are present in the analysed specimens. The bone cortex is well vascularised throughout

301 (see also Enlow \& Brown, 1958), with an irregular pattern, i.e. radial, oblique, but mainly

302 longitudinal primary vascular canals. Lutreolina shows a primary bone matrix that is dominated

303 by parallel-fibered bone with simple primary longitudinal and radial to oblique vascular canals

304 (Figs. 3D-F). Remodelled areas are characterised by partially oblique secondary osteons (Fig.

305 3F). The inner circumferential layer is thin and formed by lamellar bone. The outer

306 circumferential layer is, if present, formed by parallel-fibered bone. LAGs are not developed.

307 The vascularity is less dense than in Didelphis. The combination of parallel-fibered bone with

308 low vascularisation suggests slow apposition rates (Chinsamy-Turan, 2012b; Huttenlocker,

309 Woodward \& Hall, 2013).

310 Xenarthra - Early contributions on xenarthran bone histology are Quekett $(1849 ; 1855)$

311 and Enlow and Brown (1958). Because dermal armour is an outstanding feature of xenarthrans,

312 several studies focussed on the histology of osteoderms (e.g. Wolf, 2007; Wolf, 2008; Chávez-

313 Aponte et al., 2008; Hill, 2006; Vickaryous \& Hall, 2006; Krmpotic et al., 2009; Vickaryous \&

314 Sire, 2009; Wolf, Kalthoff \& Sander, 2012; Da Costa Pereira et al., 2012). These data, which

315 otherwise are not available, shed light on soft tissue structures of extinct xenarthrans, their

316 phylogenetic relationships, and their functional morphology. The most detailed study up to date

317 dealing with xenarthran long bone histology was performed by Straehl et al., 2013 (but see also

318 Ricqlès, Taquet \& Buffrénil, 2009). Straehl and colleagues sampled 67 long bones of 19 genera

319 and 22 xenarthran species and studied bone microstructure as well as bone compactness trends.

320 Primary bone tissue consists of a mixture of woven, parallel-fibred, and lamellar bone. 
321 Irregularly shaped vascular canals show longitudinal, reticular, or radial orientation. Anteaters

322 are the only sampled taxa showing laminar orientation. Armadillo long bones are characterised

323 by obliquely oriented secondary osteons in transverse sections, reflecting their complex

324 morphology. LAGs are common in xenarthrans although being restricted to the outermost part of

325 the bone cortex in armadillo long bones. Moreover, cingulates (armadillos and closely relative

326 extinct taxa) show lower bone compactness than pilosans (sloths) and an allometric relationship

327 between humeral and femoral compactness. Straehl and colleagues emphasise that remodelling is

328 more developed in larger taxa as indicated by dense Haversian bone in adult specimens and

329 discuss increased loading as a possible cause. Amson et al. (2014) assessed the timing of

330 acquisition of osteosclerosis (increase in bone compactness) and pachyostosis (increase in bone

331 volume) in long bones and ribs of the aquatic sloth Thalassocnus from the Neogene of Peru as

332 the main osteohistological modifications of terrestrial tetrapods returning to water. They showed

333 that such modifications can occur during a short geological time span, i.e. ca 4 Ma. Furthermore,

334 the strongly remodelled nature of xenarthran bone histology allowed the reassignment of a rib

335 previously ascribed to a sirenian to the aquatic sloth (Amson et al., 2015).

336 Afrotheria - Early contributions on the bone histology of afrotherians are Aeby (1878)

337 and Schaffer (1890) on sirenians and proboscideans, Nopcsa \& Heidsieck (1934) on sirenians,

338 Vanderhoof (1937), Enlow \& Brown (1958), Kaiser (1960), Mitchell (1963; 1964) on sirenians

339 and desmostylians, and Ezra \& Cook (1959) as well as Cook, Brooks \& Ezra-Cohn (1962) on

340 elephantids. Ricqlès \& Buffrénil (1995) described pachyosteosclerosis in the sirenian

341 Hydrodamalis gigas. Buffrénil et al. $(2008 ; 2010)$ studied the ribs of 15 extant and extinct

342 sirenian species representing 13 genera, one desmostylian, and 53 specimens of 42 extant species

343 of terrestrial, aquatic, or amphibious mammals. In those studies, primary bone tissue in young 
344 specimens is constituted by fibrolamellar bone, whereas with increasing age, parallel-fibred bone 345 tissue with longitudinal vascular canals and frequent LAGs is deposited. The authors showed that 346 pachyostosis is subsequently regressed during evolution of the clade. In contrast, only by the end 347 of the Eocene, osteosclerosis was fully developed. Furthermore, Buffrénil et al. argued that 348 variable degrees of pachyostosis and osteosclerosis in extinct and extant sirenians were caused 349 by similar heterochronic mechanisms bearing on the timing of osteoblast activity. Hayashi et al. 350 (2013) analysed the histology of long bones, ribs, and vertebrae of four genera of desmostylians 351 (usually considered as tethytherians, but see Cooper et al., 2014) and 108 specimens of extant 352 taxa (ribs: 19 taxa, humeri: 62 taxa, femora: 16 taxa, vertebrae: 11 taxa) with various 353 phylogenetic positions and ecologies by using thin sections and CT-scan data. Primary bone 354 tissue in desmostylians consisted of parallel-fibred bone with multiple LAGs. By comparisons 355 with extant mammals, they found that Behemetops and Palaeoparadoxia show osteosclerosis, 356 Ashoroa pachyosteosclerosis (i.e. a combination of increase in bone volume and compactness), while Desmostylus shows an osteoporotic-like pattern (i.e. decrease in bone compactness) instead. Since it is known from extant mammals that increasing bone mass provides hydrostatic buoyancy and body trim control suitable for passive swimmers and shallow divers, whereas spongy bones are associated with hydrodynamic buoyancy control in active swimmers, they concluded that all desmostylians achieved an essentially aquatic lifestyle. However, the basal taxa Behemotops, Paleoparadoxia, and Ashoroa could be interpreted as shallow water swimmers hovering slowly or walking on the bottom, whereas the derived taxon Desmostylus was a more active swimmer. The study has therefore shown that desmostylians are the second mammalian group after cetaceans to show a shift from bone mass increase to decrease during their

366 evolutionary history. 
As several tethytherian taxa are aquatic, the question of the ancestral lifestyle of the clade

368

369

370

371

372

373

374

375

376

377

378

379

380

381

382

383

384

385

386

387

388

389

was raised. A femur and a humerus of the Eocene proboscidean Numidotherium were sampled by Mahboubi et al. (2014). These authors recognised "large medullar cavities" (p. 506), which were considered suggestive of terrestrial habits. However, the illustrations provided by Mahboubi et al. (2014) show no opened medullary cavity, and trabecular bone occupies most of the cross-sectional area (labelled "medullary bone" by Mahboubi et al., 2014: Fig. 4). Sander \& Andrassy (2006) described the bone tissue of long bones from Mammuthus primigenius as laminar fibrolamellar bone. Due to poor preservation of the fossil bone tissue, the authors have not been able to definitely confirm the occurrence of LAGs. The valuable study of Curtin et al. (2012) dealt with two aspects of bone histology. First, they described for the first time the bone tissue of fifteen bones (femora and tibiae) of eleven specimens of late-term-fetal, neonatal, and young juvenile extant and extinct elephantids representing four species, including the insular dwarf mammoth Mammuthus exilis from the Late Pleistocene of Santa Rosa Island of the Californian Channel Islands. The bone tissue they found was predominantly laminar fibrolamellar bone. Remarkable was a distinct change in tissue microstructure marking the boundary between prenatal and postnatal bone deposition, i.e. a higher amount of large longitudinal vascular canals suggesting slightly higher postnatal growth rates. Secondly, besides histological thin sections, Curtin and colleagues employed synchrotron microtomography (SR$\mu \mathrm{CT}$ ) for noninvasively obtaining high-resolution image-“slices”. They showed that, in

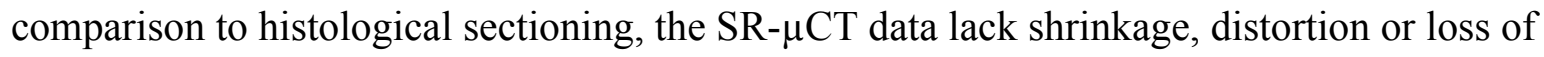
tissue, as is usually the case in histological sections. However, they stated that the quality of histological detail observable is by far superior in histological thin sections. The virtual microtomography enabled the authors to rank specimens by ontogenetic stage and quantified 
390

391

392

393

394

396

397

398

399

400

401

402

403

404

405

406

407

408

409

410 411 burial.

vascular patterns. They showed that bones of the Columbian mammoth, M. columbi had the thickest and largest number of laminae, whereas the insular dwarf mammoth, M. exilis, was characterised by its variability in that regard. The authors concluded that, qualitatively, patterns of early bone growth in elephantids are similar to those of juveniles of other tetrapods, including dinosaurs.

Notoungulata - Notoungulates are an extinct, largely diverse, endemic group of Cenozoic South American mammals, ecologically similar to current hoofed ungulates. Only four taxa (Toxodon, Nesodon, Mesotherium, and Paedotherium) were subject to histological studies (Ricqlès, Taquet \& Buffrénil, 2009; Forasiepi et al., 2014; Tomassini et al., 2014) from the more than 150 species recognised in the group. The bone samples were characterised by a wellvascularised compact cortex with mostly longitudinal vascular canals. Few irregularly oriented canals could be found. Osteocyte lacunae were large and very abundant. Haversian bone was recorded in Toxodon, Nesodon, and Mesotherium. This is a common feature in mammalian bone (Enlow \& Brown, 1958), probably caused by increased loading in large-bodied species as discussed by Straehl et al. (2013) for xenarthrans. Areas of primary bone matrix were visible between secondary osteons, which displayed a mostly parallel-fibered to lamellar organisation. Localized areas of woven bone characterised by round osteocyte lacunae were also present. The most external layer of the cortex consisted of parallel-fibred bone with very few secondary osteons and was in clear contrast to the heavily remodelled inner cortex. The study of Tomassini et al. (2015) on the palaeohistology of hemimandibles of Paedotherium bonaerense from the early Pliocene of Argentina discussed the processes affecting fossil remains before and after 
Pantodonta - Pantodonts are an extinct group of mammals that comprised large-bodied,

413 heavily built omnivores and herbivores from the Paleocene and Eocene of Laurasia. Only one

414 study (Enlow and Brown 1958) examined their bone histology. A rib of the Eocene pantodont

415 Coryphodon showed primary lamellar bone with longitudinal vascularisation.

416 Laurasiatheria - Eulipotyphla - The comprehensive work of Enlow \& Brown (1958) was

417 the first contribution on eulipotyphlan bone histology. They described the primary bone tissue of

418 a Talpa tibia and a Sorex mandible as almost completely avascular lamellar bone. A humerus and

419 radius from a juvenile showed in their outer cortex a "disorganised" (Enlow \& Brown, (1958: p.

420 190) called it, being accompanied by oblique, radial, circumferential or longitudinal simple

421 vascular canals). Klevezal (1996) discussed eulipotyphlan histology by emphasising growth

422 marks (LAGs) in the bone cortex of mandibles and their value for skeletochronology. Meier et

423 al. (2013) studied the bone compactness of humeri from eleven extant and eight fossil talpid

424 species and two non-talpid species. They could not detect any pattern of global compactness

425 related to biomechanical specialization, phylogeny, or size and concluded that at this small size

426 the overall morphology of the humerus plays a predominant role in absorbing load. Morris

427 (1970) evaluated the applicability of LAGs in extant hedgehog mandibles and found high

428 correlation between age and LAG count.

429 In the giant galericine "hedgehog" Deinogalerix from the palaeoisland of Gargano (Table

430 1), Italy, the bone tissue at the inner layer of femur RGM.178017 and humerus RGM.425360 is

431 characterised by parallel-fibred bone, whereas the outer layer and the trabecular bone is

432 composed of lamellar bone (Figs. 4A-C). In the bone cortex, simple longitudinal vascular canals

433 and primary osteons are present. Primary bone tissue is partially replaced by secondary osteons. 
434 In a femur corresponding to an adult individual, five LAGs can be distinguished (Fig. 4C)

435 indicating a minimum age of five years.

436 Chiroptera - Enlow \& Brown (1958) described the primary bone tissue in chiropterans as

437 lamellar bone surrounding a non-cancellous medullary cavity. Klevezal (1996) described the

438 presence of LAGs in chiropteran bone tissue. Herdina et al. (2010) described the bone tissue of

439 the baculum from three Plecotus species as lamellar bone surrounding a small medullary cavity

440 similar to the arrangement of a Haversian system whereas the ends of the bone consisted of

441 woven-fibred bone.

442 Perissodactyla - Enlow \& Brown (1958), Sander \& Andrassy (2006), Cuijpers (2006),

443 and Hillier \& Bell (2007) described long bones and ribs of fossil and extant equids as being

444 primarily plexiform fibrolamellar with longitudinal vascular canals, accompanied by extensive

445 remodelling including the occurrence of dense Haversian bone. Zedda et al. (2008) found much

446 Haversian tissue in extant horses and cattle. Osteons of the horse were more numerous and

447 composed of a higher number of well-defined lamellae when compared to those of cattle.

448 Diameter, perimeter, and area of osteons and Haversian canals were always higher in horses than

449 in cattle and this pattern was related to their different locomotor behaviour. However, Hillier and

450 Bell (2007) found non-significant differences between Haversian canals of horses and cattle.

451 Enlow and Brown (1958) additionally described a stratified, circumferential pattern of vascular

452 canals in a mandible of a Miocene chalicothere (Moropus), i.e. laminar fibrolamellar bone tissue

453 sensu Francillion-Vieillot et al. (1990). The authors demonstrated an identical pattern of bone

454 tissues and vascular canals in several ribs of fossil tapirs from the Eocene. Sander \& Andrassy

455 (2006) described bone tissue of tibiae of Late Pleistocene woolly rhinocerotid (Coelodonta

456 antiquitatis). They found predominantly laminar fibrolamellar bone as primary bone type besides 
457 a high amount of Haversian bone. Ricqlès, Taquet \& Buffrénil (2009) described the distribution

458 of primary and secondary bone as well as vascularisation in thin sections of several extant and

459 extinct perissodactyls including chalicotheres.. Cooper et al. (2014) considered anthracobunids

460 as stem-perissodactyls, and concluded osteosclerosis in limb bones and ribs of anthracobunids to

461 be consistent with the occupation of shallow-water habitats. Martinez-Maza et al. (2014)

462 analysed the bone tissue of humeri, femora, tibiae and metapodials of the equid Hipparion

463 concudense from the upper Miocene site of Los Valles de Fuentidueña (Spain) and showed that

464 the number of growth marks is similar across the different limb bones. They distinguished four

465 age groups and determined that Hipparion concudense tended to reach skeletal maturity during

466 its third year of life. Martinez-Maza et al. (2014) identified ontogenetic changes in bone structure

467 and growth rate and distinguished three histological stages of ontogeny corresponding to

468 immature, subadult, and adult individuals. Nacarino-Meneses, Jordana \& Köhler (in press)

469 studied an ontogenetic series of Equus hemionus (Asiatic wild ass). They analysed growth marks

470 in femora of different ontogenetic stages. Bone tissue types and vascular canal orientation varied

471 both during ontogeny and within a cross-section. Skeletochronology generally fitted previous age

472 estimates from dental eruption patterns. A wild adult female attained skeletal maturity at the age

473 of four, a wild male at five years of age.

474 A rib of the giant rhinocerotoid Paraceratherium sp. (Fig. 1G, Table 1) from the Late

475 Oligocene of Turkey displays dense Haversian bone (Fig. 1I), whereas the bone cortex is heavily

476 recrystallised and does not allow observations on primary bone.

477 Cetartiodactyla - Enlow \& Brown (1958) gave a comprehensive overview on the bone

478 histology of artiodactyls. The Miocene artiodactyls Merycoidodon and Leptomeryx showed in

479 mandibles, maxillas, and ribs a reticular pattern of primary vascularisation next to secondary 
480 Haversian tissue. Extant taxa showed essentially plexiform fibrolamellar bone in long bones and 481 reticular bone tissue in skull bones and mandibles. Singh, Tonna \& Gandel (1974) studied the 482 long bone tissue of a mature specimen of the blue duiker Cephalophus manticola, and two 483 perinatal specimens of the Indian sambar Cervus unicolor and the reindeer Rangifer tarandus. 484 Whereas Cephalophus showed primary longitudinal vascularisation, the perinatal cervids 485 revealed a reticular pattern of vascular canals. Plexiform fibrolamellar bone (Figs. 1B, 1C, 1E, 486 1F) was confirmed as primary bone tissue in artiodactyls in subsequent publications (Klevezal 1996; Horner, Ricqlès \& Padian, 1999; Cuijpers, 2006; Sander \& Andrassy, 2006; Hillier et al., 2007; Köhler et al., 2012; Marin-Moratalla, Jordana \& Köhler, 2013; Kolb et al., 2015; Jordana et al., in press). Marin-Moratalla et al. (2014) identified the primary bone tissue in bovids as laminar to plexiform. They studied 51 femora representing 27 ruminant species in order to determine the main intrinsic or extrinsic factors shaping the vascular and cellular network of fibrolamellar bone. Specifically, the authors examined the correlation of certain life history traits in bovids, i.e. body mass at birth and adulthood as well as relative age at reproductive maturity. Quantification of vascular orientation and vascular and cell densities revealed that there is no correlation with broad climatic categories or life history. Instead, the authors found correlation with body mass since larger bovids showed more circular canals and lower cell densities than did smaller bovids. Mitchell and Sander (2014) suggested a three front model consisting of an apposition front, a Haversian substitution front, and a resorption front, and applied this model successfully to a humerus of red deer Cervus elaphus. They found moderate apposition and remodelling as well as slow resorption in the red deer specimen. Hofmann, Stein \& Sander (2014) examined the lamina thickness in bone tissue (LD) in sauropodomorph dinosaurs and 17 mammalian taxa, including artiodactyls and perissodactyls. They found that LD is relatively 
503 constrained within the groups and that mean mammalian LD differs significantly from mean

504 sauropodomorph LD. In suids, LD was higher than in other mammals. The authors therefore

505 concluded that laminar vascular architecture is most likely determined by a combination of

506 structural, functional as well as vascular supply and physiological causes.

507 For the present study, the bone cortex of one small (CKS 110/B), one intermediate (CKS

508 122/B), and one large juvenile (subadult; CKS 117) of the extinct Pleistocene dwarf

509 hippopotamid of Cyprus, Hippopotamus minor (also called Phanourios minor, see van der Geer

510 et al., 2010), were examined (Table 1). In the juvenile femora the bone tissue is characterised by

511 reticular to plexiform fibrolamellar bone with an endosteal, inner circumferential layer consisting

512 of lamellar bone (Fig. 5). The bone is generally highly vascularised with primary longitudinal

513 vascular canals and primary osteons towards the outer part of the cortex. There are no Haversian

514 systems in the small juvenile (Fig. 5B), although their content increases during ontogeny and is

515 highest in the subadult specimen. Although heavily recrystallized, an adult tibia of

516 Hippopotamus minor shows strong remodelling with partially dense Haversian bone occurring

517 from the inner to the outermost part of the cortex. Towards the outer cortex of the subadult femur

518 (Fig. 5D) and typically for large mammals, the amount of parallel-fibred bone within the

519 fibrolamellar complex increases, indicating a decrease in growth rate.

520 Another taxon sampled for the current study is Sinomegaceros yabei (Table 1), which is,

521 as Megaloceros, a large-sized megacerine deer. Although a thorough description is prevented by

522 the suboptimal preservation of the specimens, some of their histological features can be

523 described here. The primary bone of the inner cortex is highly vascularised, being formed by

524 fibrolamellar tissue with a mostly plexiform vascularisation. The outer cortex is in turn weakly

525 vascularised. The adult femur OMNH QV-4062 features seven LAGs (Fig. 6), with a $2.57 \mathrm{~mm}$ 
526 thick second growth zone, which is even greater than the extreme values found in the elk, Alces

527 and Megaloceros (Kolb et al., 2015), and which indicates, as in the latter taxa, a high growth 528 rate.

529 Several authors focused on the bone histology of cetaceans and sirenians for their 530 peculiar aquatic lifestyle. Enlow \& Brown (1958) described the primary bone tissue of skull

531 bones and vertebrae of the porpoise (Phocoena phocoena) as featuring a reticular vascularisation 532 with a high amount of remodelling including the occurrence of dense Haversian bone. Buffrénil 533 and colleagues studied the microstructure of bone tissue from baleen whales in several works.

534 They found annually deposited well-defined LAGs in mandibular bone tissue of the common 535 porpoise, Phocoena phocoena (Buffrénil, 1982). The humeral bone tissue of the common 536 dolphin (Delphinus delphis) shows a cancellous texture without an open medullary cavity and 537 during ontogeny more bone eroded than deposited, indicating an osteoporotic-like process 538 (Buffrénil \& Schoevaert, 1988). Buffrénil \& Casinos (1995), by using standard microscopic 539 methods, and Zylberberg et al. (1998), by using scanning and transmission electron microscopy, 540 studied the rostrum of the extant Blainville's beaked whale Mesoplodon densirostris,

541 demonstrating a high density because of hypermineralised tissue with longitudinal fibres in dense

542 Haversian bone. Buffrénil, Dabin \& Zylberberg (2004) demonstrated that the petro-tympanic

543 bone complex in common dolphins consists of reticular to laminar fibrolamellar bone, initially

544 being deposited as loose spongiosa with hypermineralised tissue and without Haversian

545 remodelling. Two Eocene archaeocete taxa featured pachyostosis with hyperostosis (excessive 546 bone growth) of the periosteal cortex very similar to the condition present in some sirenians

547 (Buffrénil et al., 1990). The comparative study by Gray et al. (2007) analysed the ribs of ten 548 specimens representing five extinct cetacean families from the Eocene as they made their 
549 transition from a terrestrial/semiaquatic to an obligate aquatic lifestyle over a 10-million-year

550 period. The authors compared those data to nine genera of extant mammals, amongst them

551 modern dolphins, and found profound changes in microstructure involving a shift in bone

552 function. The mechanisms of osteogenesis were flexible enough to accommodate the shift from a

553 typical terrestrial form to one presenting osteosclerosis and pachyosteosclerosis, and then to

554 osteoporosis in the first quarter of the evolutionary history of cetaceans. The limb bones and ribs

555 of Indohyus, a taxon closely related to cetaceans, featured osteosclerosis, and considered

556 indicative of the use of bottom-walking as swimming mode (Thewissen et al., 2007; Cooper et

557 al., 2012). Ricqlès, Taquet \& Buffrénil (2009) published the description of a rediscovered

558 collection of thin sections from the $19^{\text {th }}$ century French palaeontologist Paul Gervais including

559 sections of cetacean bones. The most recent study on the bone microstructure of cetaceans is the

560 one of Houssaye, Muizon \& Gingerich (2015) analysing the bone microstructure of ribs and

561 vertebrae of 15 archaeocete specimens, i.e. Remingtonocetidae, Protocetidae, and Basilosauridae

562 using microtomography and virtual thin-sectioning (i.e. CT scanning). They found bone mass

563 increase in ribs and femora, whereas vertebrae are essentially spongeous. Humeri changed from

564 compact to spongeous whereas femora in basilosaurids became, once spurious for locomotion,

565 reduced, displaying strong osteosclerosis. The authors concluded that Remingtonocetidae and

566 Protocetidae probably swam in shallow water, whereas basilosaurids, for their osseous

567 specializations similar to those of modern cetaceans, are considered capable of active swimming

568 in the open-sea.

569 Creodonta - As it is the case for many other vertebrate taxa, Enlow and Brown (1958)

570 are still the only workers who analysed the "creodonts", mammalian predators from the

571 Paleogene and Early Neogene of North America, Africa, and Eurasia,. Bone tissue from 
572 mandibles, ribs, and long bones consists of primary lamellar bone with longitudinal/radial

573 vascularisation and secondary Haversian tissue, generally similar to the bone tissue found in 574 modern carnivorans.

575 Carnivora - Enlow \& Brown (1958) studied the mandible bone tissue of Ursus and found 576 primary reticular bone and secondary dense Haversian bone, whereas a rib showed only dense 577 Haversian bone. In the outer part, the bone cortex of Ursus consisted of plexiform bone. 578 Chinsamy, Rich \& Vickers-Rich (1998) found several LAGs in the zonal bone cortex of the 579 polar bear. Hayashi et al. (2013) reported that the polar bear (Ursus maritimus) has microanatomical features close to those of active swimmers in its limb bones, particularly in the humerus. The microanatomy of the femur is intermediate between aquatic and terrestrial taxa, despite its morphological features, which do not show particular adaptation for swimming. However, $U$. maritimus long bones still display a true medullary cavity. The authors suggested that this result, notably the apparently stronger adaptation of the humerus for an aquatic mode of life, is probably linked to its swimming style because $U$. maritimus uses the forelimbs as the main propulsors during swimming. Mephitis (skunk), Procyon (raccoon), Mustela (badger), Felis (cat), Canis (dog), and Urocyon (fox) all possess reticular and radial primary bone (Enlow \& Brown 1958). However, the bone cortex of adult specimens in these taxa was dominated by secondary Haversian bone. The outer cortex of Canis was composed of primary plexiform bone tissue. The mongoose (Herpestes) showed in its femur primary longitudinal vascularised bone devoid of Haversian remodelling whereas the bone cortex of the American mink (Neovison vison) was composed of reticular and Haversian bone. 
595 longitudinal vascularisation. Klevezal \& Kleinenberg (1969) found annual LAGs in the bone cortex of carnivorans. Several works dealt with the accuracy of LAGs in carnivorans in comparison to dental histology as a tool of age determination: Johnston \& Beauregard (1969) (Mustela, Martes), Pascal \& Castanet (1978) (Felis). The outcome was always in favour of dental cementum analysis. Buffrénil \& Pascal (1984) concluded that in mink mandibles the deposition of LAGs is not strictly annual by using fluorescein and alizarin labelling. The long bones of Valenictus, a Pliocene walrus (Odobenidae), were described as being osteosclerotic (Deméré, 1994). Nakajima \& Endo (2013) and Nakajima, Hirayama \& Endo (2014) analysed humeral microanatomy of multiple carnivore taxa including terrestrial, semiaquatic and fully-aquatic taxa. The authors used CT-scans and found variations of bone organisation in the centre of bone ossification and in the humeral head among carnivorans including different modes of life. Cancellousness in the centre of bone ossification is relatively low in the semiaquatic taxa like the sea otter and is relatively high both in terrestrial taxa like the wolverine and highly aquatic taxa such as the southern elephant seal. Trabeculae in humeral heads are fine and well-organised in terrestrial to semi-aquatic taxa, while trabeculae from aquatic taxa are rather coarse and randomly oriented. Euarchontoglires - Rodentia - Early contributions to rodent bone histology were made by Foote (1911a), Enlow \& Brown (1958) as well as Singh, Tonna \& Gandel (1974). More

614 recent works are by Klevezal (1996) on rest lines and age determination, Martiniakova et al. 615 (2005) on rat bone histology, and Garcia-Martinez et al. (2011) on the bone histology of 616 dormice. The bone tissue of rodents mainly consists of lamellar or parallel-fibred bone with 
617 reticular, radial or longitudinal vascularisation as primary bone tissue. Development of

618 Haversian systems is rare. Geiger et al. (2013) studied the bone cortex of a femur of the giant

619 caviomorph Phoberomys pattersoni from the Miocene of Trinidad, and found it to be composed

620 of lamellar-zonal bone. The sampled specimen showed alternating layers of compacted coarse

621 cancellous bone and parallel-fibered/lamellar primary bone with a reticulum-like structure. The

622 authors reported Haversian tissue absent. Montoya (2014) examined the bone microstructure of

623 the extant subterranean rodent Bathyergus suillus (Bathyergidae). The author found thickening

624 compacta during ontogeny in contrast to cursorial and bipedal mammals.Females of Bathyergus

625 suillus displayed a wide variation of microanatomical parameters with resorptive activity already

626 from juvenile ontogenetic stages.

627

The femoral bone cortex of Mikrotia magna, a giant insular murine rodent from the Late

Miocene former island of Gargano (Italy; Table 1), consists merely of compact bone. The bone

matrix of the middle part of the cortex is dominated by parallel-fibred bone with poor

630

longitudinal but mainly reticular vascularisation being pervaded by mainly irregularly shaped

and obliquely oriented secondary osteons (Figs. 7A-C), producing a distinct disorganised pattern

632 (Enlow \& Brown, 1958). Additionally, delimited areas of fibrolamellar bone occur within the

middle cortex. The inner and outer parts of the cortex are formed by lamellar bone with poor

longitudinal but mainly radial vascularisation. The thickness of those parts varies throughout the circumference of the bone cortex and between samples, and intercalated thin layers consisting of woven-fibred bone are present.. All the samples display LAGs. In the adult femur RGM.792085, four to five LAGswere counted. Resorption cavities are present close to the medullary cavity.

639 (Table 1) are characterised by a compact cortex. The primary bone matrix, which is only present 
640 in the outermost periosteal part of the cortex, was formed by avascular lamellar bone. The rest of

641 the cortex consists of compact coarse cancellous bone displaying thick layers of endosteal

642 lamellar bone with poor longitudinal to radial vascularisation and areas of endosteal infilling of

643 intertrabecular spaces with lamellar bone (Figs. 7D-F; Enlow, 1962; Francillon-Vieillot et al.,

644 1990; Prondvai et al., 2012). The compact coarse cancellous bone is in turn invaded by mainly

645 irregularly shaped and obliquely oriented secondary osteons. LAGs are absent in the sampled

646 specimen. Large resorption cavities and small areas of fibrolamellar bone occur.

647 Lagomorpha - For this study four different species of ochotonids (Prolagus) were

648 investigated (Table 1). One mainland form (Prolagus oeningensis from La Grive France) and

649 three island forms: The giant species Prolagus sardus (Sardinia, Italy) (Fig. 8A) and $P$.

650 imperialis along with $P$. apricenicus, both from Gargano, Italy. Generally, the bone cortex of the

651 femur and the humerus of Prolagus is compact. It is characterised by a bone matrix changing

652 from fibrolamellar to parallel-fibered into lamellar bone from the inner cortex towards the OCL

653 (Figs. 8B-F). An endosteal lamellar layer is present. In most specimens the fibrolamellar or

654 parallel-fibred bone is partly pervaded by mainly irregularly shaped and obliquely oriented

655 secondary osteons, producing the "subendosteal layer of Haversian-like bone" sensu Pazzaglia et

656 al. (2015: Fig. 6B). The primary bone cortex is in general weakly vascularised. Within the

657 primary fibrolamellar and parallel-fibred bone, primary and simple longitudinal vascular canals

658 as well as radial and reticular vascular canals occur and are arranged in an irregular manner.

659 LAGs indicating minimum ages are present in some adult specimens. Prolagus oeningensis

660 (Figs. 8B, 8C) has a maximum number of three LAGs, Prolagus apricenicus a maximum of two

661 LAGs, and Prolagus imperialis as well as Prolagus sardus each havea maximum of five (Figs.

662 8D-F). Femora from juvenile Prolagus oeningensis (PIMUZ A/V 4532) and Prolagus sardus 
663 (NMB Ty. 4974; Fig. 8E) as well as a humerus from a juvenile Prolagus imperialis

664 (RGM.792102) are characterised in the inner and middle part of the cortex by longitudinal, 665 radial, and reticular vascularised fibrolamellar bone with a high amount of woven bone. Towards 666 the bone surface, the amount of parallel-fibered bone increases and the vascularisation changes 667 into longitudinal simple and primary vascular canals. Primary bone tissue in juveniles is already 668 invaded by mainly irregularly shaped and obliquely oriented secondary osteons in the inner and 669 middle part of the cortex. Our observations on lagomorph bone histology essentially agree with 670 Foote's (1911a) and Enlow \& Brown's (1958) observations on lagomorphs. The same is the case 671 for the study of Pazzaglia et al. (2015), who studied rabbit (Oryctolagus cuniculus) femora of 672 different ontogenetic stages via micro CT-scanning. However, what they call laminar 673 respectively plexiform bone tissue is not in agreement with the nomenclature of Francillon674 Vieillot et al. (1990) used by us, i.e. longitudinal, radial, and reticular vascularisation. Moncunill675 Solé et al. (in press) provided mass estimates of $350 \mathrm{~g}$ for the extinct continental Prolagus $\mathrm{cf}$. 676 calpensis, and $280-600 \mathrm{~g}$ for Prolagus apricenicus based on femoral measurements. Bone 677 histological analysis suggests a longevity for Prolagus apricenicus of at least seven years (five 678 years more than in our sample of $P$. apricenicus). Again, the bone histological traits observed in 679 Moncunill-Solé et al. (in press) are essentially in agreement with our findings in Prolagus. Primates - Again, Enlow \& Brown (1958) were the first to describe the bone tissue of 681 extinct primates by sampling a mandible of the fossil Paleocene Plesiolestes and long bones of 682 modern primates. The authors described primary bone tissue formed by lamellar bone. 683 Vascularisation was mainly characterised by longitudinal primary vascular canals. Remodelling 684 was locally abundant and the organisation of Haversian bone was dense in some areas of the 685 bone cortex. Those observations have been confirmed by the comparative studies of Cuijpers 
686 (2006) and Hillier \& Bell (2007) as well as in the conceptual studies of Bromage et al. (2009; see 687 also above) and Castanet (2006; see also above). Castanet et al. (2004; see also above) found the 688 inner and thicker part of the bone cortex of Microcebus formed by parallel-fibred bone 689 containing primary blood vessels and scarce primary osteons. In contrast, the outer part of the 690 cortex is not vascularised. Crowder \& Stout (2012) have compiled a book covering the current 691 utilisation of histological analysis of bones and teeth within the field of anthropology, including 692 the biology and growth of bone, histomorphological analysis, and age determination. Extensive 693 literature on hominoids, especially on bone pathologies in Homo sapiens, exists. To remain 694 within the scope of this work, we cite here only some examples of those publications specific to this area. Martinez-Maza, Rosas \& García-Vargas (2006) and Martinez-Maza et al. (2011) analysed bone surfaces under the reflected light and scanning electron microscope in order to decipher modelling and remodelling patterns in extant hominine facial skeletons and mandibles as well as in Neanderthal mandibles, explaining specific morphological traits. Schultz and Schmidt-Schultz (2014) examined fossil human bone and reviewed the methods and techniques of light microscopy, scanning electron microscopy, and the advantages of polarisation microscopy for palaeoanthropology. In this context it is noteworthy that the estimation of individual age in anthropology is carried out by mainly two methods (Schultz \& SchmidtSchultz, 2014): (1) the histomorphometric method (HMM) and (2) the histomorphologic method

704 (HML). The HMM method is applied primarily to long bones (e.g. Kerley, 1965; Drusini, 1987) and is based upon the frequencies of osteons (Haversian systems), fragmented osteons

706 (interstitial lamellae), non-Haversian canals, and the percentage of the external circumferential

707 lamellae. The HML method is based upon the morphology (presence, size, shape, development) 708 of external and internal circumferential lamellae, osteons, fragmented osteons, and non- 
709 Haversian canals (e.g. Schultz, 1997). Skinner et al. (2015) studied the pattern of trabeculae 710 distributions of metacarpals in Australopithecus africanus and Pleistocene hominins. They found

711 a 'human-like' pattern, considered to be consistent with tool use. Ryan \& Shaw (2015) quantified

712 the proximal femur trabecular bone structure using micro-CT data from 31 extant primate taxa

713 (229 individuals) and four distinct archaeological human populations (59 individuals)

714 representing sedentary agriculturalists and mobile foragers. Trabecular bone variables indicate

715 that the forager populations had significantly higher bone volume fraction, thicker trabeculae,

716 and lower relative bone surface area compared with the two agriculturalist groups. The authors

717 did not find any significant differences between agriculturalist and forager populations for

718 trabecular spacing, number, or degree of anisotropy. Ryan \& Shaw concluded there was a

719 correspondence between human behaviour and bone structure in the proximal femur, indicating

720 that more highly mobile human populations have trabecular bone structure similar to what would

721 be expected for wild non-human primates of the same body mass, thus emphasising the

722 importance of physical activity and exercise for bone health and the attenuation of age-related

723 bone loss.

724

725

726

\section{Selected contributions on mammalian histology}

Many excellent papers on mammalian histology have appeared over the years, and we

727 cannot discuss all of them. However, we feel that a number of these deserve a more detailed evaluation as they address important aspects of applications of palaeohistological work. Enlow \& Brown's (1958) outstanding comparative work on mammalian bone histology is not further mentioned in this section, since it is repeatedly discussed above. 
of rest lines in the bone cortex of mammals for skeletochronological studies (see also ChinsamyTuran, 2005). In their work, which was originally published in Russian in 1967, they found that in mammals, unlike the zonal bone forming in reptiles, the recording part including LAGs is the outer or periosteal zone (see also above). Klevezal (1996) found that rest lines are not formed from the first year of life in every mammalian taxon. Therefore, she suggested a variable correction factor for different mammalian taxa and concluded that the best structures for recording growth and age are dentine and especially cementum (Klevezal, 1996). In her detailed and comprehensive study of recording structures in mammals, she found that the growth rate of a particular structure can change according to the growth rate of the whole organism and that seasonal changes of growth intensity of an animal as a whole determine the formation of growth layers. Klevezal (1996) argued that changes in humidity, not temperature, may play a role as a seasonal factor in growth. tibiae and metatarsals) of herbivorous mammals from the Late Pleistocene of Germany comprising the extinct giant deer Megaloceros giganteus, the red deer Cervus elaphus, the reindeer Rangifer tarandus, the extinct bovids Bos primigenius and Bison priscus, the equid Equus sp., the extinct rhinocerotid Coelodonta antiquitatis, and the extinct elephantid Mammuthus primigenius. All samples showed fibrolamellar bone and a varying degree of remodelling and most of the long bones displayed LAGs. The authors questioned the argument that LAGs in dinosaur bone indicate ectothermy because of the frequently found LAGs in endothermic animals. 
754 Pleistocene bovid from the Balearic Islands. They found lamellar-zonal tissue throughout the

755

756

757

758

759

760

761

762

763

764

765

766

767

768

769

770

771

772

773

774

775

cortex, a trait exclusive to ectothermic reptiles. According to Köhler and colleagues, Myotragus

grew unlike any other mammal but similar to crocodiles, i.e. at slow and flexible rates, ceased

growth periodically, and attained somatic maturity late after twelve years. The authors concluded that this developmental pattern indicates that Myotragus, much like extant reptiles, synchronized its metabolic requirements with fluctuating resource levels.

Kolb et al. (2015) performed a histological analysis of long bones and teeth representing eleven extinct and extant cervid taxa, amongst them the dwarf island morphotypes of

Candiacervus from the Late Pleistocene of Crete and the giant deer Megaloceros giganteus, both in a clade together with fallow deer (Dama dama) among extant species. Bone tissue types observed were similar, indicating a comparable mode of growth across the eight species examined, with long bones mainly possessing primary plexiform fibrolamellar bone (Figs. 1B, 1C, 1E, 1F). Dwarf Candiacervus were characterised by low growth rates, Megaloceros by high rates, and the lowest recorded rates were those of the Miocene small stem cervid Procervulus praelucidus. It should be noted that Sinomegaceros yabei, sampled for the present study, features a very thick second growth zone, which suggests a high growth rate, comparable to that of the closely related Megaloceros. Skeletal maturity estimates (see also above) indicated late attainment in sampled Candiacervus and Procervulus. Tooth cementum analysis of first molars of two senile Megaloceros giganteus specimens revealed ages of 16 and 19 years whereas two old dwarf Candiacervus specimens gave ages of 12 and 18 years. Kolb et al. (2015) concluded that the bone histological condition found in Candiacervus had features in common with that of Myotragus (Köhler \& Moyà-Solà, 2009), but was achieved with a lesser modification of bone 
776 tissue and suggested various modes of life history and size evolution among island mammals.

777 Amson et al. (in press) examined further 'stem-cervid' bone histology in describing that of other

778 Miocene taxa, Dicrocerus elegans and Euprox sp. With their inclusion in the dataset of Kolb et

779 al. (2015), they estimated ancestral growth rates among cervids, and studied their correlation

780 with body size. The skeletochronology of Dicrocerus and Euprox suggested relatively high and

781 intermediate growth rates respectively for their body sizes, differing from the condition of

782 Procervulus, and hence documenting diversity in the life history traits of Miocene cervids.

783 Dumont et al. (2013) documented the microstructure of vertebral centra using 2D

784 histomorphometric analyses of vertebral centra from 98 therian mammal species that cover the

785 main size ranges and locomotor adaptations known in therian taxa. The authors extracted eleven

786 variables relative to the development and geometry of trabecular networks from CT scan mid-

787 sagittal sections. Random taxon reshuffling and squared change parsimony indicated a

788 phylogenetic signal in the majority of the variables. Furthermore, based on those variables, it was

789 possible to determine three categories of locomotion among the sampled taxa: a) terrestrial +

790 flying + digging + amphibious forms, b) coastal oscillatory aquatic taxa, and c) pelagic

791 oscillatory aquatic forms represented by oceanic cetaceans. Dumont and colleagues concluded

792 that, when specific size increases, the length of trabecular networks, as well as trabecular

793 proliferation, increase with positive allometry. They found that, by using six structural variables,

794 locomotion mode can be predicted with a $97.4 \%$ success rate for terrestrial forms, $66.7 \%$ for

795 coastal oscillatory, and $81.3 \%$ for pelagic oscillatory.

796

797 Discussion on bone histology of island mammals 
Within our overview, we have a large sample of insular mammals. Islands have their own

799

800

801

802

803

804

805

806

807

808

809

810

811

812

813

814

815

816

817

818

819

set of rules when it comes down to evolution (van der Geer et al., 2010; Lomolino et al. 2012;

Lomolino et al. 2013), and in the following we explore to what extent insular evolution may effect bone histology.

Three juvenile specimens of the dwarf island hippopotamid Hippopotamus minor from the Late Pleistocene of Cyprus show reticular to plexiform fibrolamellar bone, which does not indicate an island-specific pattern of bone growth or life history but a mode of growth similar to continental artiodactyl relatives instead. The bone cortex of the dormouse Leithia sp. from the Pleistocene of Sicily is characterised by primary lamellar bone and a high amount of compact coarse cancellous bone. Mikrotia magna, the giant island rodent from the Late Miocene of Gargano, Italy shows in the middle part of the cortex parallel-fibred bone with reticular vascularisation and mainly irregularly shaped and obliquely oriented secondary osteons. The inner and outer parts of the cortex are formed by lamellar bone. García-Martínez et al. (2011) did not find compact coarse cancellous bone in their sample of extant dormice. The high amount of compact coarse cancellous bone and therefore strong inward growth (Enlow, 1962) in our Leithia sp. specimen might point towards an island specific modification of bone tissue. However, sampling of more specimens in order to confirm this observation is necessary. The composition of bone tissues found in Mikrotia magna is in general similar to the one encountered in extant murid rodents (Foote, 1911; Enlow, 1958; Enlow, 1962; Singh, Tonna \& Gandel, 1974;

Martiniaková et al., 2005). The partially high amount of remodelling encountered in Mikrotia is likely related to high individual ages. In the bone cortex of three fossil species of insular giant Prolagus and the fossil continental lagomorph Prolagus oeningensis are mainly parallel-fibred 
820 bone and reticular, radial as well as longitudinal vascularisation indicating a similarity of bone

821 histological arrangements in continental and island species of rodents and lagomorphs.

822 The highest age found in Prolagus sardus and P. imperialis of five years are well within

823 the known longevities of extant ochotonids such as Ochotona princeps (seven years in captivity)

824 and O. hyperborean (9.4 years in captivity) (Tacutu et al., 2013). Moncunill-Solé et al. (in press)

825 suggested a longevity for Prolagus apricenicus of at least seven years (five years more than in

826 our sample of $P$. apricenicus). Based on the predictions by the body mass inferred, Moncunill et

827 al. (in press) suggested a move to the slow end of the fast-slow continuum (maturing later and

828 fewer offspring) in Prolagus apricenicus. A minimal individual age deduced from growth marks

829 in the bone tissue of Deinogalerix specimen RGM 178017 lies also well within the known

830 longevities for extant erinaceids such as Erinaceus europaeus (11.7 years in captivity), $E$.

831 concolor (seven years in captivity), and E. amurensis (9.4 years in captivity). Longevity data for

832 extant galericines are not yet available (Tacutu et al., 2013).

833 The insular dwarf bovid Myotragus balearicus from Majorca showed an important

834 decrease in bone growth rate and an evolution towards a slow life history, i.e. delayed maturity

835 and long lifespan (Köhler and Moyà-Solà, 2009; Köhler, 2010; Jordana \& Köhler, 2011; Jordana

836 et al., 2012; Moncunill-Solé et al., in press; but see Raia, Barbera \& Conte (2003) for an opposite

837 case of life history modification in Sicilian dwarf elephants). The authors suggest these findings

838 to be trends for island mammals in agreement with McArthur \& Wilson (1967), as well as life

839 history theory (Stearns, 1992) and that the degree of these modifications depends on multiple

840 factors such as island size, distance from mainland, climate, phylogeny, time of evolution and

841 others (see also Moncunill-Solé et al., 2014). Myotragus dwelt on Majora for 5.2 Ma and

842 therefore underwent an exceptionally long time of evolution (van der Geer et al., 2010) and 
843 resource limitation (Köhler \& Moyà-Solà, 2009). A similarly high degree of bone histological

844 and life history modification as described by Köhler \& Moyà-Solà (2009) for Myotragus in

845 comparison to continental artiodactyls has not been recorded for the insular mammals

846 Deinogalerix sp., Hippopotamus minor, Leithia sp., Mikrotia magna, or for several species of

847 Prolagus in comparison to their mainland relatives.

848 A variable degree of modification in bone tissue and life history could be related to shorter

849 persistence times and different island size (Lomolino et al., 2012; Lomolino et al., 2013; Kolb et

850 al., 2015)., in line with Austad \& Fischer (1991), McNab (1994; 2002; 2010), Raia, Barbera \&

851 Conte (2003), Curtin et al. (2012), and Kolb et al. (2015).

852

853 Conclusions

854 A large variety of bone tissues and vascularisation patterns is encountered in mammalian 855 bone reaching from lamellar or parallel-fibred to fibrolamellar or woven-fibred bone, largely 856 depending on taxon and individual age. A plexiform to laminar organisation of vascular canals

857 within fibrolamellar bone is typically found in taxa containing large-bodied species such as non858 mammalian cynodonts, laurasiatherians, and afrotherians. The deposition of Haversian systems 859 throughout ontogeny of non-mammalian cynodonts and mammals is common. Table 2 gives a 860 summary on general patterns of bone histological features encountered in major cynodont clades.

861 We suggest the presence of various modes of bone histological modification and

862 mammalian life history evolution on islands depending on factors of island evolution such as 863 island size, distance from mainland, climate, phylogeny, and time of evolution. Further bone

864 histological comparisons and sampling of more specimens as well as species of fossil insular 
865 endemics and their mainland relatives within an ontogenetic framework would contribute

866 significantly to the knowledge of the ecology of past island ecosystems.

867

868 Future research fields

869 New technologies - 3D reconstructions attained by virtual image analysis gain increasing

870 importance for palaeontological research at the anatomical, microanatomical, and even

871 histological levels (Sanchez et al., 2012; Clément \& Geffard-Kuriyama, 2010; Curtin et al.,

872 2012; see also Ricqlès, 2011). The potential advantages of virtual imaging as a method are

873 evident: Firstly, specimens are not damaged by invasive sampling. Secondly, a third dimension,

874 usually achieved by time consuming serial sectioning or preparation of orthogonally oriented

875 thin sections, is easily realizable. Thirdly, virtual imaging techniques allow continuous

876 "zooming" from the histological to the micro- and macronatomical levels of structural

877 organisation. High resolution synchrotron virtual histology provides new 3D insights into the

878 submicron-scale histology of fossil and extant bones. This is based on the development of new

879 data acquisition strategies, pink-beam configurations, and improved processing tools (Sanchez et

880 al., 2012). Nevertheless, for the high resolution optical properties of a polarisation microscope

881 and its applications for identification and analysis of bone microstructure, as well as for the

882 comparatively low amount of financial resources needed, traditional thin sections are far from

883 being completely replaced by virtual imaging techniques. Moreover, new statistical methods

884 allow extraction of phylogenetic signals from bone microstructures and of high specimen

885 numbers (Laurin, 2004; Laurin, Girondot \& Loth, 2004; Cubo et al., 2008). In addition to a

886 phylogenetic signal, bone tissues are also influenced by biomechanical and ecological signals

887 (Cubo et al., 2005; Cubo et al., 2008; Laurin, Girondot \& Loth, 2004; Laurin et al., 2004; Ricqlès 
888 \& Cubo, 2010; Hayashi et al., 2013). Here too, the advances in high performance computers and 889 software open possibilities to investigate the variability in bone tissues by taking multiple factors 890 into account. The creation of histological databases will soon be necessary due to an increasing 891 number of palaeohistological publications and growing collections of thin sections (Ricqlès, 892 Castanet \& Francillon-Vieillot, 2004; Ricqlès, Taquet \& Buffrénil, 2009; Bromage, 2006; Kriloff 893 et al., 2008; Scheyer, 2009-2015; Canoville \& Laurin, 2010; O’Leary \& Kaufmann, 2012). Extant vertebrate biology - Actualistic models are essential for the interpretation of fossil hard tissues in every sense, no matter if developmental and life historical, histophysiological, morphological, ecological, or systematic. Living animals present the basis for inferring palaeobiological conclusions and this has already been performed in several bone histological works (e.g. Canoville \& Laurin, 2010; Köhler et al., 2012, Marin-Moratalla, Jordana \& Köhler, 2011; Marin-Moratalla et al., 2014; Kolb et al. 2015). In regard to deciphering life history signals, the actualistic approach is fundamental and will become increasingly more so (e.g. Köhler et al., 2012; Marin-Moratalla, Jordana \& Köhler, 2013; Marin-Moratalla et al., 2014; Kolb et al., 2015). Life history variables such as annual growth rate, skeletal/sexual maturity, and longevity and their signal in bone microstructure help to understand palaeobiology not only of fossil mammals but also of tetrapods in general. It is possible to use bone histology to quantify growth rates and vascularisation or cellular density in mammals as a relative proxy for growth rate (Curtin et al., 2012; Kolb et al., 2015; MarinMoratalla, Jordana \& Köhler, 2013; Marin-Moratalla et al., 2014; Jordana et al., in press), whereby the existing literature on the paleobiology of dinosaurs has been used as a starting point. However, not every methodological approach used for dinosaurs is applicable or relevant for 910 mammals (e.g. Erickson, Curry Rogers \& Yerby, 2001; Griebeler, Klein \& Sander, 2013; Kolb et 
911 al., 2015). No one stated it better than Armand de Ricqlès: „The possibilities of using bone

912 histology of extant vertebrates for various fundamental or applied research, whether on life

913 history traits, ecology, or microevolution, are simply boundless.“ (Ricqlès, 2011).

914

\section{Acknowledgments}

916 Alexandra Wegmann and Fiona Straehl are thanked for their help with the bone

917 histological preparation, Madeleine Geiger for the fruitful discussions (all Palaeontological

918 Institute of the University of Zurich (PIMUZ), Switzerland), and Ashley Latimer (PIMUZ) and

919 Cathy Ridgway for English corrections. Likewise, we thank Xavier Jordana and P. Martin

920 Sander for their thorough and critical reviews, which helped greatly to improve the manuscript.

921

922

References

923 Aeby C. 1878. Das histologische Verhalten fossilen Knochen- und Zahngewebes. Archiv für 924 Mikroskopische Anatomie 15:371-382.

925 Agustí J, and Antón M. 2002. Mammoths, sabertooths and hominids. New York: Columbia 926 University Press.

927 Amprino R. 1947. La structure du tissu osseux envisagee comme l'expression de différences dans 928 la vitesse de l'accroissement. Archives de Biologie 58:315-330.

929 Amson E, Muizon C de, Laurin M, Argot C, and Buffrénil V de. 2014. Gradual adaptation of 930 bone structure to aquatic lifestyle in extinct sloths from Peru. Proceedings of the Royal Society $931 \quad B$ 281:1-6.

932 Amson E, Muizon C de, Domning DP, Argot C, and Buffrénil V de. 2015. Bone histology as a 933 clue for resolving the puzzle of a dugong rib in the Pisco Formation, Peru. Journal of Vertebrate 934 Paleontology: e922981.

935 Amson E, Kolb C, Scheyer TM, and Sánchez-Villagra MR. in press. Growth and life history of 936 middle Miocene deer (Mammalia, Cervidae) based on bone histology. Comptes Rendus Palevol 937 in press. 
938 Austad SN, and Fischer KE. 1991. Mammalian aging, metabolism, and ecology: Evidence from 939 the bats and marsupials. Journal of Gerontology 46:B47-53.

940 Boef M de, and Larsson HCE. 2007. Bone microstructure: quantifying bone vascular 941 orientation. Canadian Journal of Zoology 85:63-70.

942 Botha J, and Chinsamy A. 2000. Growth patterns deduced from the bone histology of the 943 cynodonts Diademodon and Cynognathus. Journal of Vertebrate Paleontology 20:705-711.

944 Botha J, and Chinsamy A. 2004. Growth and life habits of the Triassic cynodont Trirachodon, 945 inferred from bone histology. Acta Palaeontologica Polonica 49:619-627.

946 Botha J, and Chinsamy A. 2005. Growth patterns of Thrinaxodon liorhinus, a non-mammalian 947 cynodont from the Lower Triassic of South Africa. Palaeontology 48:385-394.

948 Botha-Brink J, Abdala F, and Chinsamy A. 2012. The radiation and osteohistology of 949 nonmammaliaform cynodonts. In: Chinsamy-Turan A, ed. Forerunners of mammals: radiation, 950 histology, biology. Bloomington: Indiana University Press, 223-246.

951 Bromage TG. 2006. Donald H. Enlow Digital Image Library. Available at 952 http://www.nyu.edu/dental/enlow/(accessed 13 May 2015).

953 Bromage TG, Lacruz RS, Hogg R, Goldman HM, McFarlin SC, Warshaw J, Dirks W, Perez954 Ochoa A, Smolyar I, Enlow DH, and Boyde A. 2009. Lamellar bone is an incremental tissue 955 reconciling enamel rhythms, body size, and organismal life history. Calcified Tissue 956 International 84:388-404.

957 Buffrénil V de. 1982. Données préliminaires sur la présence de lignes d'arret de croissance 958 périostiques dans la mandibule du marsouin commun, Phocoena phocoena (L.), et leur 959 utilisation comme indicateur de I'age. Canadian Journal of Zoology 60:2557-2567.

960 Buffrénil V de, Astibia H, Pereda Suberbiola X, and Berreteaga A. 2008. Variation in bone 961 histology of middle Eocene sirenians from western Europe. Geodiversitas 30:425-432.

962 Buffrénil V de, Canoville A, D’Anastasio R, and Domning DP. 2010. Evolution of sirenian 963 pachyosteosclerosis, a model-case for the study of bone structure in aquatic tetrapods. Journal of 964 Mammalian Evolution 17:101-120.

965 Buffrénil V de, and Casinos A. 1995. Observations histologiques sur le rostre de Mesoplodon 966 densirostris (Mammalia, Cetacea, Ziphiidae): le tissu osseux le plus dense connu. Annales des 967 Sciences Naturelles, Zoologie, Paris, 13e Série 16:21-36.

968 Buffrénil V de, and Castanet J. 2000. Reptiles age estimation by skeletochronology in the Nile 969 Monitor (Varanus niloticus), a highly exploited species. Journal of Herpetology 34:414-424. 
970 Buffrénil V de, Dabin W, and Zylberberg L. 2004. Histology and growth of the cetacean petro971 tympanic bone complex. Journal of Zoology 262:371-381.

972 Buffrénil V de, and Pascal B. 1984. Croissance et morphogenèse postnatales de la mandibule du 973 vison (Mustela vison, Schreiber): données sur la dynamique et l'interprétation fonctionnelle des 974 dépots osseux mandibulaires. Canadian Journal of Zoology 62:2026-2037.

975 Buffrénil V de, Ricqlès Ad, Ray CE, and Domning DP. 1990. Bone histology of the ribs of the 976 archaeocetes (Mammalia: Cetacea). Journal of Vertebrate Paleontology 10:455-466.

977 Buffrénil V de, and Schoevaert D. 1988. On how the periosteal bone of the delphinid humerus 978 becomes cancellous: ontogeny of a histological specialization. Journal of Morphology 198:149979164.

980 Bybee PJ, Lee AH, and Lamm ET. 2006. Sizing the Jurassic theropod dinosaur Allosaurus: 981 assessing growth strategy and evolution of ontogenetic scaling of limbs. Journal of 982 Morphology 267:347-359.

983 Canoville A, and Laurin M. 2010. Evolution of humeral microanatomy and lifestyle in amniotes, 984 and some comments on palaeobiological inferences. Biological Journal of the Linnean 985 Society 100:384-406.

986 Castanet J. 1994. Age estimation and longevity in reptiles. Gerontology 40:174-192.

987 Castanet J. 2006. Time recording in bone microstructures of endothermic animals; functional 988 relationships. Comptes Rendus Palevol 5:629-636.

989 Castanet J, Croci S, Aujard F, Perret M, Cubo J, and de Margerie E. 2004. Lines of arrested 990 growth in bone and age estimation in a small primate: Microcebus murinus. Journal of 991 Zoology 263:31-39.

992 Castanet J, and Smirina EM. 1990. Introduction to the skeletochronological method in 993 amphibians and reptiles. Annales des sciences naturelles, Zoologie 11:191-196.

994 Chávez-Aponte EO, Alfonzo-Hernández I, Finol HJ, Barrios N. CE, Boada-Sucre A, and 995 Carrillo-Briceño JD. 2008. Histologia y ultraestructura de los osteodermos fosiles de Glyptodon 996 clavipes y Holmesina sp. (Xenarthra: Cingulata). Interciencia 33:616-619.

997 Chinsamy A, and Abdala F. 2008. Palaeobiological implications of the bone microstructure of 998 South American traversodontids (Therapsida: Cynodontia). South African Journal of 999 Science 104:225-230.

1000 Chinsamy A, and Hurum JH. 2006. Bone microstructure and growth patterns of early 1001 mammals. Acta Palaeontologica Polonica 51:325-338. 
1002 Chinsamy A, Rich T, and Vickers-Rich P. 1998. Polar dinosaur bone histology. Journal of 1003 Vertebrate Paleontology 18:385-390.

1004 Chinsamy-Turan A. 2005. The microstructure of dinosaur bone: Deciphering biology with fine 1005 scale techniques. Baltimore: Johns Hopkins University Press.

1006 Chinsamy-Turan A. 2012a. Forerunners of mammals: radiation, histology, biology. Life of the 1007 past. Bloomington: Indiana University Press. p 352.

1008 Chinsamy-Turan A. 2012b. Microstructure of bones and teeth of nonmammalian therapsids. In: 1009 Chinsamy-Turan A, ed. Forerunners of mammals: radiation, histology, biology. Bloomington: 1010 Indiana University Press, 65-88.

1011 Clément G, and Geffard-Kuriyama D. 2010. Imaging and 3D in palaeontology and 1012 palaeoanthropology. Comptes Rendus Palevol 9:259-264.

1013 Cook SF, Brooks ST, and Ezra-Cohn HE. 1962. Histological studies on fossil bone. Journal of 1014 Paleontology 36:483-494.

1015 Cooper LN, Seiffert ER, Clementz M, Madar SI, Bajpai S, Hussain ST, and Thewissen JGM.

1016 2014. Anthracobunids from the middle eocene of India and pakistan are stem

1017 perissodactyls. PloS one 9:e109232.

1018 Cooper LN, Thewissen JGM, S. Bajpai S, and Tiwari BN. 2012. Postcranial morphology and 1019 locomotion of the Eocene raoellid Indohyus (Artiodactyla: Mammalia). Historical

1020 Biology 24:279-310.

1021 Cormack D. H. 1987. Ham's histology. Philadelphia: J. B. Lippincott Company.

1022 Crowder C, and Stout S. 2012. Bone histology: an anthropological perspective. Boca Raton: 1023 CRC Press.

1024 Cubo J, Legendre P, Ricqlès A de, Montes L, Margerie E de, Castanet J, and Desdevise Y. 2008. 1025 Phylogenetic, functional and structural components of variation in bone growth rate in 1026 amniots. Evolution and Development 10:217-227.

1027 Cubo J, Ponton F, Laurin M, Margerie E de, and Castanet J. 2005. Phylogenetic signal in bone 1028 microstructure of sauropsids. Systematic Biology 54:562-574.

1029 Cuijpers A. 2006. Histological identification of bone fragments in archaeology: telling humans 1030 apart from horses and cattle. International Journal of Osteoarchaeology 16 465-480.

1031 Curtin AJ, Macdowell AA, Schaible EG, and Roth L. 2012. Noninvasive histological 1032 comparison of bone growth patterns among fossil and extant neonatal elephantids using 1033 synchrotron radiation X-ray microtomography. Journal of Vertebrate Paleontology 32:939-955. 
1034 Da Costa Pereira PVLG, Victer GD, Porpino KDO, and Bergqvist LP. 2012. Osteoderm

1035 histology of Late Pleistocene cingulates from the intertropical region of Brazil. Acta

1036 Palaeontologica Polonica 59:543-552.

1037 Deméré TA. 1994. Two new species of fossil walruses (Pinnipedia: Odobenidae) from the upper 1038 Pliocene San Diego Formation, California. Proceedings of the San Diego Society of Natural

1039 History 29:77-98.

1040 Drusini AZ. 1987. Refinement of two methods for the histomorphometric determination of age

1041 in human bone. Zeitschrift für Morphologie und Anthropologie 77:167-176.

1042

1043

1044

1045

1046

1047

1048

1049

1050

1051

1052

1053

1054

1055

1056

1057

1058

1059

1060

1061

1062

1063

1064

1065

1066

Dumont M, Laurin M, Jacques F, Pellé E, Dabin W, and Buffrénil V de. 2013. Inner architecture of vertebral centra in terrestrial and aquatic mammals: a two-dimensional comparative study. Journal of Morphology 274:570-584.

Enlow DH. 1962. A study of the postnatal growth and remodeling of bone. American Journal of Anatomy 110:79-101.

Enlow DH, and Brown SO. 1958. A comparative histological study of fossil and recent bone tissues. Part III. Texas Journal of science 10:187-230.

Erickson GM. 2014. On dinosaur growth. Annual Review of Earth and Planetary Sciences 42:675-697.

Erickson GM, Curry Rogers K, and Yerby SA. 2001. Dinosaurian growth patterns and rapid avian growth rates. Nature 412:429-433.

Erickson GM, Makovicky PJ, Currie PJ, Norell MA, Yerby SA, and Brochu CA. 2004.

Gigantism and comparative life-history parameters of tyrannosaurid dinosaurs. Nature 430:772775.

Ezra HC, and Cook SF. 1959. Histology of mammoth bone. Science 129 465-466.

Forasiepi AM, Cerdeño E, Bond M, Schmidt GI, Naipauer M, Straehl FR, Martinelli AG, Garrido AC, Schmitz MD, and Crowley JL. 2014. New toxodontid (Notoungulata) from the Early Miocene of Mendoza, Argentina. Paläontologische Zeitschrift DOI 10.1007/s12542-0140233-5.

Foote JS. 1911a. The comparative histology of femoral bones. Transactions of the American Microscopical Society 30:87-140.

Foote JS. 1911b. Preliminary Notice Transactions of the American Microscopical Society 30:326-327.

Francillon-Vieillot H, Buffrénil V de, Castanet J, Géraudie J, Meunier FJ, Sire JY, and Ricqlès A de. 1990. Microstructure and mineralization of vertebrate skeletal tissues. In: Carter JG, editor. 
1067 Skeletal Biomineralization: Patterns, Processes and Evolutionary Trends. New York: Van 1068 Nostrand Reinhold. p 471-530.

1069 Frylestam B, and von Schantz T. 1977. Age determination of European hares based on periosteal 1070 growth lines. Mammal Review 7:151-154.

1071 Garcia-Martinez R, Marin-Moratalla N, Jordana X, and Köhler M. 2011. The ontogeny of bone 1072 growth in two species of dormice: Reconstructing life history traits. Comptes Rendus 1073 Palevol 10:489-498.

1074 Geiger M, Wilson LAB, Costeur L, Sánchez R, and Sánchez-Villagra MR. 2013. Diversity and 1075 body size in giant caviomorphs (Rodentia) from the Northern Neotropics - study of femoral 1076 variation. Journal of Vertebrate Paleontology 33:1449-1456.

1077 Gray NM, Kainec K, Madar S, Tomko L, and Wolfe S. 2007. Sink or Swim? Bone density as a 1078 mechanism for buoyancy control in early cetaceans. Anatomical Record 290:638-653.

1079 Griebeler EM, Klein N, and Sander PM. 2013. Aging, maturation and growth of 1080 sauropodomorph dinosaurs as deduced from growth curves using long bone histological data: an 1081 assessment of methodological constraints and solutions. PloS one 8: e67012.

1082 Gross W. 1934. Die Typen des mikroskopischen Knochenbaues bei fossilen Stegocephalen und 1083 Reptilien. Zeitschrift für Anatomie und Enwicklungsgeschichte 103:731-764.

1084 Habermehl K-H. 1985. Altersbestimmung bei Wild-und Pelztieren - Möglichkeiten und 1085 Methoden - Ein praktischer Leitfaden für Jäger, Biologen und Tierärzte. Hamburg, Berlin: 1086 Verlag Paul Parey.

1087 Hayashi S, Houssaye A, Nakajima Y, Chiba K, Ando T, Sawamura H, Inuzuka N, Kaneko N, 1088 and Osaki T. 2013. Bone inner structure suggests increasing aquatic adaptations in Desmostylia 1089 (Mammalia, Afrotheria). PloS one 8:e59146.

1090 Herdina AN, Herzig-Straschil B, Hilgers H, Metscher BD, and Plenk HJ. 2010.

1091 Histomorphology of the penis bone (baculum) in the gray long-eared bat Pleocotus 1092 austriacus (Chiroptera, Vespertilionidae). The Anatomical Record 293:1248-1258.

1093 Hill RV. 2006. Comparative anatomy and histology of xenarthran osteoderms. Journal of 1094 Morphology 267:1441-1460.

1095 Hillier ML, and Bell LS. 2007. Differentiating human bone from animal bone: A review of 1096 histological methods. Journal of Forensic Sciences 52:249-263.

1097 Hofmann R, Stein K, and Sander PM. 2014. Constraints on the lamina density of laminar bone 1098 architecture of large-bodied dinosaurs and mammals. Acta Palaeontologica Polonica 59 2871099294. 
1100 Horner JR, Ricqlès A de, and Padian K. 1999. Variation in dinosaur skeletochronology 1101 indicators: implications for age assessment and physiology. Paleobiology 25:295-304.

1102 Horner JR, Ricqlès A de, and Padian K. 2000. Long bone histology of the hadrosaurid dinosaur Maiasaura peeblesorum: growth dynamics and physiology based on an ontogenetic series of skeletal elements. Journal of Vertebrate Paleontology 20:115-129.

1105

1106

1107

1108

1109

1110

1111

1112

1113

1114

1115

1116

1117

1118

1119

1120

1121

1122

1123

1124

1125

1126

1127

1128

1129

1130

Horner JR, and Padian K. 2004. Age and growth dynamics of Tyrannosaurus rex. Proceedings of the Royal Society of London B 271:1875-1880.

Houssaye A, P. T, Muizon C de, and Gingerich PD. 2015. Transition of Eocene whales from land to sea: evidence from bone microstructure. PloS one 10:e118409.

Huttenlocker AK, Woodward HN, and Hall BK. 2013. The biology of bone. In: Padian K, and Lamm E-T, eds. Histology of fossil tetrapods - Advancing methods, analysis and interpretation. Berkeley, Los Angeles, London: University of California Press, 13-34.

Johnston DH, and Beauregard M. 1969. Rabies epidemiology in Ontario. Bulletin of the Wildlife Disease Association 5:357-370.

Jordana X, and Köhler M. 2011. Enamel microstructure in the fossil bovid Myotragus balearicus (Majorca, Spain): implications for life-history evolution of dwarf mammals in insular ecosystems. Palaeogeography, Palaeoclimatology, Palaeoecology 300:59-66.

Jordana X, Marín-Moratalla N, DeMiguel D, Kaiser TM, and Köhler M. 2012. Evidence of correlated evolution of hypsodonty and exceptional longevity in endemic insular mammals. Proceedings of the Royal Society of London B: Biological Sciences 279:3339-3346.

Jordana X, Marín-Moratalla N, Moncunill-Solè B, Nacarino-Meneses C, and Köhler M. in press. Ontogenetic changes in the histological features of zonal bone tissue of ruminants: a quantitative approach. Comptes Rendus Palevol.

Kaiser HE. 1960. Untersuchungen zur vergleichenden Osteologie der fossilen und rezenten Pachyostosen. Palaeontographica Abteilung A 114:113-196.

Kerley ER. 1965. The microscopic determination of age in human bone. American Journal of Physical Anthropology 23:149-163.

Kielan-Jaworowska Z, Cifelli RL, and Luo XZ. 2004. Mammals from the age of dinosaurs: origins, evolution, and structure. New York: Columbia University Press.

King CM. 1991. A review of age determination methods for the stoat Mustela erminea. Mammal Review 21:31-49. 
1131 Kiprijanoff W. 1881. Studien über die fossilien Reptilien Russlands. I. Theil. Gattung 1132 Ichthyosaurus König. Mémoires de l'Académie des Sciences de St-Pétersbourg, VIIe Série Tome 1133 XXVIII 8:1-103.

1134 Klein N, and Sander PM. 2008. Ontogenetic stages in the long bone histology of sauropod 1135 dinosaurs. Paleobiology 34:247-263.

1136 Klevezal GA. 1996. Recording structures of mammals. Determination of age and reconstruction 1137 of life history. Rotterdam/Brookfield: A.A.Balkema.

1138 Klevezal GA, and Kleinenberg SE. 1969. Age determination of mammals from annual layers in 1139 teeth and bones. Jerusalem: Israel Program of Scientific Translations.

1140 Köhler M. 2010. Fast or slow? The evolution of life history traits associated with insular 1141 dwarfing. In: Pérez-Mellado V, and Ramon C, editors. p 261-280.

Köhler M, Marín-Moratalla N, Jordana X, and Aanes R. 2012. Seasonal bone growth and physiology in endotherms shed light on dinosaur physiology. Nature 487:358-361.

Köhler M, and Moyà-Solà S. 2009. Physiological and life history strategies of a fossil large mammal in a resource-limited environment. Proceedings of the National Academy of Sciences of the United States of America 106:20354-20358.

Kolb C, Scheyer TM, Lister AM, Azorit C, de Vos J, Schlingemann MAJ, Rössner GE, Monaghan NT, and Sánchez-Villagra MR. 2015. Growth in fossil and extant deer and implications for body size and life history evolution. BMC Evolutionary Biology 15:1-15.

Kriloff A, Germain D, Canoville A, Vincent P, Sache M, and Laurin M. 2008. Evolution of bone microanatomy of the tetrapod tibia and its use in palaeobiological inference. Journal of Evolutionary Biology 21:807-826.

Krmpotic CM, Ciancio MR, Barbeito CG, Mario RC, and Carlini AA. 2009. Osteoderm morphology in recent and fossil euphractine xenarthrans. Acta Zoologica 90:339-351. Biology 53:594-622.

1157 Laurin M, Girondot M, and Loth M-M. 2004. The evolution of long bone microanatomy and 1158 lifestyle in lissamphibians. Palaeobiology 30:589-613.

1159 Lee AH, Huttenlocker AK, Padian K, and Woodward HN. 2013. Analysis of growth rates. In: 1160 Padian K, and Lamm E-T, eds. Bone histology of fossil tetrapods. Berkeley: University of 1161 California Press, 217-251. 
1162 Lee AH, and Werning S. 2008. Sexual maturity in growing dinosaurs does not fit reptilian 1163 growth models. Proceedings of the National Academy of Sciences of the United States of 1164 America 105:582-587.

1165 Lomolino MV, Sax DF, Palombo MR, and van der Geer AA. 2012. Of mice and mammoths: 1166 evaluations of causal explanations for body size evolution in insular mammals. Journal of 1167 Biogeography 39:842-854.

1168 Lomolino MV, van der Geer AA, Lyras GA, Palombo MR, Sax DF, and Rozzi R. 2013. Of mice 1169 and mammoths: generality and antiquity of the island rule. Journal of Biogeography 40:142711701439.

1171

1172

1173

1174

1175 1176

1177

1178

1179

1180

1181

1182

1183

1184 1185 1186

1187 1188 1189

1190 1191 1192

1193

1194

Luo XZ. 2011. Developmental Patterns in Mesozoic Evolution of Mammal Ears. Annual Review of Ecology, Evolution, and Systematics 42:355-380

Luo ZX, and Wible JR. 2005. A Late Jurassic digging mammal and early mammalian diversification. Science 308:103-107.

MacArthur RH, and Wilson EO. 1967. The theory of island biogeography. Princeton: Princeton University Press.

Maddison WP, and Maddison DR. 2015. Mesquite: a modular system for evolutionary analysis. Version 3.02. Available at http://mesquiteproject.org.

Mahboubi S, Bocherens H, Scheffler M, Benammi M, and Jaeger JJ. 2014. Was the Early Eocene proboscidean Numidotherium koholense semi-aquatic or terrestrial? Evidence from stable isotopes and bone histology. Comptes Rendus Palevol 13:501-509.

Marangoni F, Schaefer E, Cajade R, and Tejedo M. 2009. Growth mark formation and chronology of two neotropical anuran species. Journal of Herpetology 43:546-550.

Margerie E de, Cubo J, and Castanet J. 2002. Bone typology and growth rate: Testing and quantifying 'Amprino's rule' in the mallard (Anas platyrhynchus). Comptes Rendus Biologies 325:221-230.

Marín-Moratalla N, Cubo J, Jordana X, Moncunill-Solè B, and Köhler M. 2014. Correlation of quantitative bone histology data with life history and climate: a phylogenetic approach. Biological Journal of the Linnean Society 112:678-687.

Marín-Moratalla N, Jordana X, and Köhler M. 2013. Bone histology as an approach to providing data on certain key life history traits in mammals: Implications for conservation biology. Mammalian Biology 78:422-429.

Martínez-Maza C, Rosas A, and García-Vargas S. 2006. Bone paleohistology and human evolution. Journal of Anthropological Sciences 84:33-52. 
1195 Martinez-Maza C, Rosas A, Garcia-Vargas S, Estalrrich A, and de la Rasilla M. 2011. Bone 1196 remodelling in Neanderthal mandibles from the El Sidron site (Asturias, Spain). Biology

1197 Letters 7:593e596.

1198 Martinez-Maza C, Alberdi MT, Nieto-Diaz M, and Prado JL. 2014. Life history traits of the 1199 Miocene Hipparion concudense (Spain) inferred from bone histological structure. Plosone 1200 9:e103708.

1201

1202

1203

1204

1205

1206

1207

1208

1209

1210

1211

1212

1213

1214

1215

1216

1217

1218

1219

1220

1221

1222

1223

1224

1225

1226

1227

1228

Martiniaková M, Grosskopf B, Vondráková M, Omelka R, and Fabiš M. 2005. Observation of the microstructure of rat cortical bone tissue. Scripta Medica 78:45-50.

McNab B. 1994. Resource use and the survival of land and freshwater vertebrates on oceanic islands. The American Naturalist 144:643-660.

McNab BK. 2002. Minimizing energy expenditure facilitates vertebrate persistence on oceanic islands. Ecological Letters 5:693-704.

McNab BK. 2010. Geographic and temporal correlations of mammalian size reconsidered: a resource rule. Oecologia 164:13-23.

Meier PS, Bickelmann C, Scheyer, Koyabu D, and Sánchez-Villagra MR. 2013. Evolution of bone compactness in extant and extinct moles (Talpidae): exploring humeral microstructure in small fossorial mammals. BMC Evolutionary Biology 13:55.

Meredith RW, Janecka J, Gatesy J, Ryder OA, Fisher CA, Teeling EC, Goodbla A, Eizirik E, Simão TLL, Stadler T, Rabosky DL, Honeycutt RL, Flynn JJ, Ingram CM, Steiner C, Williams TL, Robinson TJ, Burk-Herrick A, Westerman M, Ayoub NA, Springer MS, and Murphy WJ. 2011. Impacts of the Cretaceous terrestrial revolution and KPg extinction on mammal diversification. Science 334:521-524.

Mitchell EDJ. 1963. Brachydont desmostylian from Miocene of San Clemente Island, California. Bulletin of the Southern California Academy of Science 62:192-201.

Mitchell EDJ. 1964. Pachyostosis in desmostylids. The Geological Society of America Special Paper 76:214.

Mitchell J, and Sander PM. 2014. The three-front model: a developmental explanation of long bone diaphyseal histology of Sauropoda. Biological Journal of the Linnean Society 112:765781.

Moncunill-Solé B, Jordana X, Marín-Moratalla N, Moyà-Solà S, and Köhler M. 2014. How large are the extinct giant insular rodents? New body mass estimations from teeth and bones.

Integrative Zoology 9:197-212.

Moncunill-Solé B, Orlandi-Oliverasa G, Jordana X, Rook L, and Köhler M. in press. First approach of the life history of Prolagus apricenicus (Ochotonidae, Lagomorpha) from Terre 
1229 Rosse sites (Gargano, Italy) using body mass estimation and paleohistological analysis. Comptes 1230 Rendus Palevol.

1231 Montoya GA. 2014. Bone microstructure of the subterranean rodent Bathyergus suillus

1232 (Rodentia: Bathyergidae) Master's thesis. University of Cape Town - South Africa.

1233 Morris P. 1970. A method for determining absolute age in the hedgehog. Journal of

1234 Zoology 161:277-281.

1235 Musser AM. 2003. Review of the monotreme fossil record and comparison of palaeontological 1236 and molecular data. Comparative Biochemistry and Physiology Part A 136 927-942.

1237 Musser AM, and Archer M. 1998. New information about the skull and dentary of the

1238 Miocene Platypus obdurodon dicksoni, and a discussion of ornithorhynchid

1239 relationships. Philosophical Transactions of the Royal Society of London B 353:1063-1079.

1240 Nacarino-Meneses C, Jordana X, and Köhler M. in press. First approach to bone histology and

1241 skeletochronology of Equus hemionus. Comptes Rendus Palevol.

1242 Nopcsa F von, and Heidsieck E. 1934. Über eine pachyostotische Rippe aus der Kreide Rügens.

1243 Acta Zoologica 15:431-455.

1244 O’Leary MA, Bloch JI, Flynn JJ, Gaudin TJ, Giallombardo A, Giannini NP, Goldberg SL, 1245 Kraatz BP, Luo Z-X, Meng J, Ni X, Novacek MJ, Perini FA, Randall ZS, Rougier GW, Sargis

1246 EJ, Silcox MT, Simmons NB, Spaulding M, Velazco PM, Weksler M, Wible JR, and Cirranello

1247 AL. 2013. The Placental Mammal Ancestor and the Post-K-Pg Radiation of

1248 Placentals. Science 339:662-667.

1249 O'Leary MA, and Kaufman SG. 2012. MorphoBank 3.0: web application for morphological 1250 phylogenetics and taxonomy. Available at http://www.morphobank.org (accessed 6 May 2015).

1251 Padian K. 2011. Vertebrate palaeohistology then and now: A retrospective in the light of the 1252 contributions of Armand de Ricqles. Comptes Rendus Palevol 10:303-309.

1253 Padian K. 2013. Book review: forerunners of mammals: radiation, histology, biology. Journal of

1254 Vertebrate Paleontology 33:1250-1251.

1255 Padian K, and Lamm E-T. 2013. Bone histology of tetrapods. Berkeley, Los Angeles: University 1256 of California Press. p 285.

1257 Pascal M, and Delattre P. 1981. Comparaison des différentes méthodes de la détermination de 1258 l'age individuel chez le vison (Mustela vison Schreber). Canadian Journal of Zoology 59:2021259211.

1260 Pascual R, Archer M, Jaureguizar EO, Prado JL, Godthelp H, and Hand SJ. 1992. First discovery 1261 of monotremes in South America. Nature 356:704 - 706. 
1262 Pazzaglia UE, Sibilia V, Congiu T, Pagani F, Ravanelli M, and Zarattini G. 2015. Setup of a 1263 bone aging experimental model in the rabbit comparing changes in cortical and trabecular bone: morphological and morphometric study in the femur. Journal of Morphology.

1265 Ponton F, Elzanowski A, Castanet J, Chinsamy A, Margerie E de, Ricqlès A de, and Cubo J. 1266 2004. Variation of the outer circumferential layer in the limb bones of birds. Acta

1267 Ornithologica 39:21-24.

1268 Prondvai E, Stein K, 0si A, and Sander PM. 2012. Life history of Rhamphorhynchus inferred 1269 from bone histology and the diversity of pterosaurian growth strategies. PloS one 7:e31392.

1270

1271

1272

1273

1274

1275

1276

1277

1278

1279

1280

1281

1282

1283

1284

1285

1286

1287

1288

1289

1290

1291

1292

1293

1294

1295

Prondvai E, Stein KHW, Ricqlès A de, and Cubo J. 2014. Development-based revision of bone tissue classification: the importance of semantics for science. Biological Journal of the Linnean Society 112:799-816.

Quekett JT. 1849a. On the intimate structure of bone as composing the skeleton in the four great classes of animals, viz., mammals, birds, reptiles, and fishes, with some remarks on the great value of the knowledge of such structure in determining the affinities of minute fragments of organic remains. Transactions of the Microscopical Society of London 2:46-58.

Quekett JT. 1849b. Additional observations on the intimate structure of bone. Transactions of the Microscopical Society of London 2:59-64.

Quekett JT. 1855. Descriptive and illustrated catalogue of the histological series contained in the museum of the Royal College of Surgeons of England. Volume II. Structure of the skeleton of vertebrate animals. London: Taylor and Francis.

Raia P, Barbera C, and Conte M. 2003. The fast life of a dwarfed giant. Evolutionary Ecology 17:293-312.

Ray S, Botha J, and Chinsamy A. 2004. Bone histology and growth patterns of some nonmammalian therapsids. Journal of Vertebrate Paleontology 24:634-648.

Ricqlès A de. 1969. Recherches palèohistologiques sur les os longs des tetrapodes. II.- Quelques observations sur la structure des os longs des thériodontes. Annales de Paléontologie 55:1-52.

Ricqlès A de. 1974. Evolution of endothermy: histological evidence. Evolutionary Theory 1:5180 .

Ricqlès A de. 1975. Recherches paléohistologiques sur les os longs des tétrapodes VII. - Sur la classification, la signification fonctionnelle et l'histoire des tissus oseux des tétrapodes. Première partie, structures. Annales de paléontologie 61, 51-129 61:51-129.

Ricqlès A de. 1976a. On bone histology of fossil and living reptiles, with comments on its functional and evolutionary significance. In: Bellairs A, and Cox CB, eds. Morphology and Biology of Reptiles. London and New York: Academic Press, 123-150. 
1296 Ricqlès A de. 1976b. Recherches paléohistologiques sur les os longs des tétrapodes. VII. - Sur la 1297 classification, la signification fonctionnelle et l'histoire des tissus osseux des tétrapodes.

1298 Deuxième partie. Fonctions: considérations fonctionnelles et physiologiques. Annales de 1299 Paléontologie 62:71-126.

1300 Ricqlès A de, and Buffrénil V de. 1995. Sur la présence de pachyostéosclerosis chez la rhytine 1301 de Steller (Rhytina (Hydrodamalis) gigas), sirénian rézent éteint. Annales des Sciences 1302 Naturelles, Zoologie, Paris, 13e Série 16:47-53.

1303 Ricqlès A de, Castanet J, and Francillon-Vieillot H. 2004. The "message" of bone tissue in 1304 Palaeoherpetology. Italian Journal of Zoology:3-12.

1305 Ricqlès A de, and Cubo J. 2010. Le problème de la causalité complexe aux sources de la relation 1306 structuro-fonctionnelle : 1/généralités, 2/l'exemple du tissu osseux. In: Gayon J, and Ricqlès Ad, 1307 eds. Les Fonctions : des organismes aux artefacts. Paris: PUF, 179-188.

Ricqlès A de, Meunier FJ, Castanet J, and Francillon-Vieillot H. 1991. Comparative microstructure of bone. In: Hall BK, ed. Bone Volume 3: Bone matrix and bone specific products. Boca Raton: CRC Press, 1-78.

1311 Ricqlès A de, Taquet $\mathrm{P}$, and Buffrénil V de. 2009. "Rediscovery” of Paul Gervais' 1312 paleohistological collection. Geodiversitas 31:943-971.

1313 Ricqlès A de. 2011. Vertebrate palaeohistology: past and future. Comptes Rendus 1314 Palevol 10:509-515.

1315

1316
Ryan TM, and Shaw CN. 2015. Gracility of the modern Homo sapiens skeleton is the result of decreased biomechanical loading. Proceedings of the National Academy of Sciences of the United States of America 112:372-377.

Sanchez S, Ahlberg P, Trinajstic K, Mirone A, and Tafforeau P. 2012. Three dimensional synchrotron virtual paleohistology: a new insight into the world of fossil bone microstructures. Microscopy and Microanalysis 18:1095-1105.

Sander PM, and Andrassy P. 2006. Lines of arrested growth and long bone histology in Pleistocene large mammals from Germany: What do they tell us about dinosaur physiology? Palaeontographica Abteilung A 277:143-159.

Sander PM, Klein N, Buffetaut E, Cuny G, Suteethorn V, and Le Loeuff J. 2004. Adaptive radiation in sauropod dinosaurs: bone histology indicates rapid evolution of giant body size through acceleration. Organisms, Diversity \& Evolution 4:165-173.

Sander PM, and Tückmantel C. 2003. Bone lamina thickness, bone apposition rates, and age estimates in sauropod humeri and femora. Paläontologische Zeitschrift 77:161-172. 
1329 Schaffer J. 1890. Über den feineren Bau fossiler Knochen. Sitzungsberichte der Kaiserlichen 1330 Akademie der Wissenschaften Mathematisch-Naturwissenschaftliche Classe XCVIII. Band. 1331 Hefte I bis X. Abtheilung III:319-382.

1332 Scheyer TM. 2009-2015. Palaeohistology. In: Sánchez-Villagra MR, editor. Developmental 1333 Palaeontology net. Zurich: Palaeontological Institute of the University of Zurich. Available at 1334 http://www.developmental-palaeontology.net/palaeohistology/index.php (accessed 1 June 2015).

1335

1336

1337

1338

1339

1340

1341

1342

1343

1344

1345

1346

1347

1348

1349

1350

1351

1352

1353

1354

1355

1356

1357

1358

1359

1360

1361

Scheyer TM, Klein N, and Sander PM. 2010. Developmental palaeontology of Reptilia as revealed by histological studies. Seminars in Cell \& Developmental Biology 21:462-470.

Schultz M. 1997. Microscopic investigation of excavated skeletal remains: a contribution to paleopathology and forensic medicine. In: Haglund WD, and Sorg MH, eds. Forensic taphonomy The postmortem fate of human remains. Boca Raton/New York/London/Tokyo: CRC Press, 201222.

Schultz M, and Schmidt-Schultz TH. 2014. Microscopic research on fossil human bone. In: Henke W, and Tattersall I, eds. Handbook of paleoanthropology. 2nd ed. Heidelberg/New York: Springer, 983-998.

Singh IJ, Tonna EA, and Gandel CP. 1974. A comparative histological study of mammalian bone. Journal of Morphology 144:421-438.

Skinner MM, Stephens NB, Tsegai ZJ, Foote AC, Nguyen NH, Gross T, Pahr DH, Hublin J-J, and Kivell TL. 2015. Human-like hand use in Australopithecus africanus. Science 347:395-399.

Stearns SC. 1992. The evolution of life histories. Oxford: Oxford University Press.

Stein K, and Prondvai E. 2013. Rethinking the nature of fibrolamellar bone: an integrative biological revision of sauropod plexiform bone formation. Biological Reviews:1-24.

Stein K, and Sander M. 2009. Histological core drilling: a less destructive method for studying bone histology. First Annual Fossil Preparation and Collections Symposium. Petrified Forest National Park: Petrified Forest. p 69-80.

Straehl FR, Scheyer TM, Forasiepi AM, MacPhee RD, and Sánchez-Villagra MR. 2013. Evolutionary patterns of bone histology and bone compactness in xenarthran mammal long bones. Plosone 8:e69275.

Tacutu R, Craig T, Budovsky A, Wuttke D, Lehmann G, Taranukha D, Costa J, Fraifeld VE, and de Magalhaes JP. 2013. Human Ageing Genomic Resources: Integrated databases and tools for the biology and genetics of ageing. Nucleic Acids Research 41:D1027-D1033.

Thewissen JGM, Cooper LN, Clementz MT, Bajpai S, and Tiwari BN. 2007. Whales originated from aquatic artiodactyls in the Eocene epoch of India. Nature 450:1190-1194. 
1362 Tomassini RL, Montalvo CI, Manera T, and Visconti G. 2014. Mineralogy, geochemistry, and 1363 paleohistology of pliocene mammals from the Monte Hermoso Formation (Argentina).

1364 Paedotherium bonaerense (Notoungulata, Hegetotheriidae) as a case study. Ameghiniana 1365 51:385-395.

1366 van der Geer A, Lyras G, de Vos J, and Dermitzakis M. 2010. Evolution of island mammals. 1367 Adaptation and extinction of placental mammals on islands. Sussex: Wiley-Blackwell.

1368 Vanderhoof VL. 1937. A study of the Miocene sirenian Desmostylus. University of California 1369 Publications in the Geological Sciences 24:169-262.

1370

1371

1372

1373

1374

1375

1376

1377

1378

1379

1380

1381

1382

1383

1384

1385

1386

1387

1388

1389

1390

1391

1392

1393
Vickaryous MK, and Hall BK. 2006. Osteoderm morphology and development in the ninebanded armadillo, Dasypus novemcinctus (Mammalia, Xenarthra, Cingulata). Journal of Morphology 267:1273-1283.

Vickaryous MK, and Sire JY. 2009. The integumentary skeleton of tetrapods: origin, evolution, and development. Journal of Anatomy 214:441-464.

Warren JW. 1963. Growth zones in the skeleton of recent and fossil vertebrates $\mathrm{PhD}$. University of California.

Wolf D. 2007. Osteoderm histology of extinct and recent Cingulata and Phyllophaga (Xenarthra, Mammalia): implications for systematics and biomechanical adaptation. Hallesches Jahrbuch für Geowissenschaften Beiheft 23:145-151.

Wolf D. 2008. Osteoderm histology of the Cingulata (Xenarthra, Mammalia): implications for systematics. Journal of Vertebrate Paleontology 28:161A.

Wolf D, Kalthoff DC, and Martin Sander PM. 2012. Osteoderm histology of the Pampatheriidae (Cingulata, Xenarthra, Mammalia): implications for systematics, osteoderm growth, and biomechanical adaptation. Journal of Morphology 273:388-404.

Woodward HN, Padian K, and Lee AH. 2013. Skeletochronology. In: Padian K, and Lamm E-T, eds. Histology of fossil tetrapods - Advancing methods, analysis and interpretation. Berkeley, Los Angeles, London: University of California Press, 195-215.

Zedda M, Lepore G, Manca P, Chisu V, and Farina V. 2008. Comparative bone histology of adult horses and cows. Journal of Veterinary Medicine Series C 37:442-445.

Zylberberg L, Traub W, Buffrénil V de, Allizard F, Arad T, and Weiner S. 1998. Rostrum of a toothed whale: ultrastructural study of a very dense bone. Bone 23:241-247. 
1394 Figure 1: Typical mammalian bone tissue as observed in large mammals such as cervids.

1395

1396

1397

1398

1399

1400

1401

1402

1403

1404

1405

1406

1407

1408

1409

1410

1411

1412

1413

1414

1415

1416
Red bars indicate area and plane of sectioning. Histological images B), E), and I) in linear

polarised light, C) in crossed polarised light and with additional use of lambda

compensator, and F) in crossed polarised light. A) Life reconstruction of the cervid

Megaloceros giganteus ("Knight Megaloceros" by Charles R. Knight, courtesy of the

American Museum of Natural History via Wikimedia Commons -

http://commons.wikimedia.org). B, C) Bone cortex of an adult tibia of Megaloceros

giganteus specimen NMING:F21306/14 displaying an endosteal lamellar layer

(innermost part of the cortex) and reticular as well as plexiform fibrolamellar primary

bone with growth marks. Note that the primary bone is pervaded by secondary Haversian

systems in the inner third of the bone cortex. White arrows indicate lines of arrested

growth. Occurrence of LAGs indicated by black/white arrows and the outer

circumferential layer (OCL) by white brackets. D) Photograph of Pudu puda ("Pudupuda

hem 8 FdoVidal Villarr 08Abr06-PhotoJimenez", courtesy of Jaime E. Jimenez via

Wikimedia Commons - http://commons.wikimedia.org). E, F) Bone cortex of an adult

femur of Pudu puda specimen NMW 60135 displaying an endosteal lamellar layer and

mainly plexiform fibrolamellar bone. G) Reconstruction of Paraceratherium

("Indricotherium11", Courtesy of Dmitry Bogdanov via Wikimedia Commons -

http://commons.wikimedia.org). H) Cross-section of a rib of Paraceratherium sp.

specimen MTA-TTM 2006-1209. Red rectangle indicates area of dense Haversian bone

magnified in I).

Figure 2: Phylogeny of Cynodontia focussing on groups discussed, based on Luo et al. (2005), Luo et al. (2011), Meredith et al. (2011), and O’Leary et al. (2013). 
1417

1418

Notoungulates and Pantodonta are not included given their controversial systematic position.

Figure 3: Femoral bone cortex of marsupials. Histological images A) and D) in linear polarised light and B), C), E), and F) in crossed polarised light. A, B) Outer bone cortex of adult Didelphis albiventris specimen PIMUZ A/V 5279. Note the occurrence of simple primary longitudinal vascular canals and primary osteons in mainly parallel-fibred bone tissue. C) Inner bone cortex of the same specimen displaying a distinct endosteal lamellar layer. D, E) Bone cortex of adult Lutreolina crassicautada specimen PIMUZ A/V 5275. F) Inner cortex of same specimen. Note the occurrence of primary longitudinal vascular canals and primary osteons as well as Haversian systems within the parallel-fibred bone.

Figure 4: Histological features of the femur of Deinogalerix sp. A) Life reconstruction of Deinogalerix koenigswaldi in comparison to the extant hedgehog Erinaceus (modified from Agustí \& Antón, 2002). B) Adult right femur (specimen RGM.178017) in anterior view. Red bar indicates area and plane of sectioning. C) Lateral bone cortex in crossed polarised light showing parallel-fibred bone and 5 LAGs. Occurrence of LAGs indicated by white arrows.

Figure 5: Bone cortex of Hippopotamus minor femora. A) Life reconstruction (from van der Geer et al., 2010; drawing: Alexis Vlachos) of another Mediterranean dwarf hippopotamid from the Middle Pleistocene of Crete. Since no life reconstruction of Hippopotamus minor is available, we here show the one of Hippopotamus creutzburgi. Histological images B), and C) in linear polarised light, D) in crossed polarised light. B) Small juvenile specimen CKS 110/B. C) Intermediate sized juvenile specimen CKS 122/B showing reticular to plexiform vascularised bone. Note that the middle part mainly 
1440

1441

1442

1443

1444

1445

1446

1447

1448

1449

1450

1451

1452

1453

1454

1455

1456

1457

1458

1459

1460

1461

1462

consists of reticular bone. D) Outer bone cortex of large juvenile specimen CKS 117 showing mainly parallel-fibred bone. Black and grey areas indicate zones of recrystallisation due to diagenetic alteration of bone tissue.

Figure 6: Histological features of Sinomegaceros yabei, the megacerine deer from the Pleistocene of Japan. Histological images in linear polarised light of an adult femur (OMNH QV-4062) depicting A) the whole cross-section and B) a close-up of the outer cortex. The red bar in A) localizes the approximated position of the section on the life reconstruction (courtesy of Hirokazu Tokugawa), and the red rectangle indicates the area of the close-up. B) Note that seven LAGs are visible, as indicated by white arrows.

Figure 7: Bone histology of fossil island rodents. Histological images A) and D) in linear polarised light, B) and E) in crossed polarised light, and C) and F) in crossed polarised light with additional use of lambda compensator. A-C) Adult Mikrotia sp. femur (specimen RGM.792085) showing disorganised, mainly parallel-fibred/lamellar bone in its centre. D-F) Adult femur of Leithia sp. specimen NMB G 2160 displaying a mainly compacted coarse cancellous cortex of endosteal lamellar bone with areas of trabecular infilling and remodelling. Please note that periosteal lamellar bone is only present close to the bone surface.

Figure 8: Bone histology of fossil ochotonids. A) Life reconstruction of Prolagus sardus ("Prolagus3", courtesy of Wikimedia Commons - http://commons.wikimedia.org). Histological images B), D), F) in linear polarised light, C) in crossed polarised light with additional use of lambda compensator, and E) in crossed polarised light. B, C) Lateral cortex of adult Prolagus oeningensis femur PIMUZ A/V 4532 showing fibrolamellar bone partially pervaded by irregular secondary osteons in the inner part and mainly 
1463

1464

1465

1466

1467

1468

1469

1470

1471 parallel-fibred bone in the middle and outer part as well as three LAGs. D) Lateral cortex of adult Prolagus imperialis femur RGM.792096 displaying an identical pattern of bone tissue but five LAGs. E) Posteromedial cortex of juvenile Prolagus sardus femur NMB Ty. 4974 showing an area of fibrolamellar bone with a high amount of woven-fibred bone in the inner part and an increasing amount of parallel-fibred bone in the middle and outer part of the cortex. F) Outer anterolateral cortex of adult Prolagus sardus femur NMB Ty.12659 displaying five LAGs. Note that the line in the lower third of the cortex is a resorption line (RL) and not a LAG. Occurrence of LAGs indicated by white or yellow arrows. 


\section{Table $\mathbf{1}$ (on next page)}

Table 1: Material used in this study.

Specimens sampled in this study with ontogenetic stage, geological age, locality of death/fossil site, and specimen number.

Institutional Abbreviations: CKS Cyprus Kissonerga collection of the University of Athens;

MTA Natural History Museum, The General Directorate of Mineral Research and Exploration, Ankara, Turkey; NMB Naturhistorisches Museum Basel, Switzerland; NMING National Museum of Ireland - Natural History; NMW Naturhistorisches Museum Wien, Austria; OMNH Osaka Museum of Natural History, Japan; PIMUZ Paläontologisches Institut und Museum, Universität Zürich, Switzerland; RGM Rijksmuseum voor Geologie en Mineralogie (now Netherlands Centre for Biodiversity Leiden) 
1 Table 1: Material used in this study. Specimens sampled in this study with ontogenetic stage, 2 geological age, locality of death/fossil site, and specimen number.

\begin{tabular}{|c|c|c|c|c|}
\hline Species & Object & $\begin{array}{l}\text { Ontogenetic } \\
\text { stage }\end{array}$ & $\begin{array}{l}\text { Geological age; } \\
\text { Locality }\end{array}$ & Specimen number \\
\hline \begin{tabular}{|l|} 
Didelphis \\
albiventris
\end{tabular} & Femur & adult & La Plata, Argentina & PIMUZ A/V 5279 \\
\hline " & " & adult & $"$ & PIMUZ A/V 5277 \\
\hline " & " & adult & $\begin{array}{l}\text { Ingeniero Mashwitzt, } \\
\text { Argentina }\end{array}$ & PIMUZ A/V 5276 \\
\hline " & " & adult & Ranchos, Argentina & PIMUZ A/V 5278 \\
\hline $\begin{array}{l}\text { Lutreolina } \\
\text { crassicautada }\end{array}$ & " & adult & Mar de Ajo, Argentina & PIMUZ A/V 5275 \\
\hline " & " & adult & La Plata, Argentina & PIMUZ A/V 5274 \\
\hline \begin{tabular}{|l} 
Leithia sp. \\
\end{tabular} & Tibia & adult & $\begin{array}{l}\text { Pleistocene; Grotta di } \\
\text { Maras, Sicily }\end{array}$ & NMB G 2160 \\
\hline Mikrotia magna & Femur & adult & $\begin{array}{l}\text { Late Miocene; Sono } \\
\text { Giovo, Gargano }\end{array}$ & RGM.792083 \\
\hline \begin{tabular}{|l} 
\\
\end{tabular} & " & adult & " & RGM.792084 \\
\hline \begin{tabular}{|l}
$"$ \\
\end{tabular} & " & adult & " & RGM.792085 \\
\hline \begin{tabular}{|l}
$"$ \\
\end{tabular} & " & adult & $"$ & RGM.792086 \\
\hline \begin{tabular}{|l} 
Prolagus \\
apricenicus
\end{tabular} & Femur & adult & $\begin{array}{l}\text { Late Miocene; San } \\
\text { Giovannino, Gargano }\end{array}$ & RGM.792087 \\
\hline " & " & adult & " & RGM.792088 \\
\hline " & " & adult & $"$ & RGM.792089 \\
\hline " & " & adult & " & RGM.792090 \\
\hline " & " & adult & " & RGM.792091 \\
\hline " & " & adult & " & RGM.702092 \\
\hline " & Humerus & adult & " & RGM.792093 \\
\hline " & " & adult & " & RGM.792094 \\
\hline
\end{tabular}




\begin{tabular}{|c|c|c|c|c|}
\hline$"$ & |" & adult & " & |RGM.792095 \\
\hline Prolagus imperialis & Femur & adult & " & RGM.792096 \\
\hline$"$ & " & adult & " & RGM.792097 \\
\hline$"$ & " & adult & " & RGM.792098 \\
\hline$"$ & $"$ & adult & " & RGM.792099 \\
\hline$"$ & " & adult & " & RGM.792100 \\
\hline$"$ & " & adult & " & RGM.792101 \\
\hline$"$ & Humerus & juvenile & " & RGM.792102 \\
\hline$"$ & " & adult & " & RGM.792103 \\
\hline$"$ & " & adult & " & RGM.792104 \\
\hline Prolagus sardus & Femur & juvenile & $\begin{array}{l}\text { Late Pleistocene; } \\
\text { Monte San Giovanni, } \\
\text { Sardinia }\end{array}$ & NMB Ty. 4974 \\
\hline$"$ & " & adult & " & NMB Ty. 4977 \\
\hline " & |" & adult & $\begin{array}{l}\text { Late Pleistocene; } \\
\text { Grotta Nicolai, Sardinia }\end{array}$ & NMB Ty.12656 \\
\hline$"$ & " & adult & " & NMB Ty.12657 \\
\hline$"$ & \begin{tabular}{|l|}
$"$ \\
\end{tabular} & adult & $\begin{array}{l}\text { Late Pleistocene; Isola } \\
\text { di Tavolara, Sardinia }\end{array}$ & NMB Ty.12658 \\
\hline$"$ & " & adult & " & NMB Ty.12659 \\
\hline $\begin{array}{l}\text { Prolagus } \\
\text { oeningensis }\end{array}$ & Femur & juvenile & $\begin{array}{l}\text { Middle Miocene; La } \\
\text { Grive, France }\end{array}$ & PIMUZ A/V 4532 \\
\hline & $"$ & adult & & PIMUZ A/V 4532 \\
\hline$"$ & " & adult & " & PIMUZ A/V 4532 \\
\hline$"$ & Humerus & adult & " & PIMUZ A/V 4532 \\
\hline$"$ & " & adult & " & PIMUZ A/V 4532 \\
\hline $\begin{array}{l}\text { Megaloceros } \\
\text { giganteus }\end{array}$ & Tibia & adult & $\begin{array}{l}\text { Late Pleistocene; } \\
\text { Baunmore Townland, } \\
\text { Rep. of Ireland }\end{array}$ & NMING:F21306/14 \\
\hline Sinomegaceros & Tibia & juvenile & $\begin{array}{l}\text { Late Pleistocene; } \\
\text { Kumaishi-do Cave, }\end{array}$ & OMNH QV-4067 \\
\hline
\end{tabular}




\begin{tabular}{|c|c|c|c|c|}
\hline yabei & & & $\begin{array}{l}\text { Miyama, Hachiman- } \\
\text { cho, Gujo City, Gifu } \\
\text { Prefecture, Japan }\end{array}$ & \\
\hline$"$ & Tibia & adult & $"$ & OMNH QV-4068 \\
\hline " & Femur & juvenile & $"$ & OMNH M-087 \\
\hline$"$ & Femur & adult & $"$ & OMNH QV-4062 \\
\hline Pudu puda & Femur & adult & $\begin{array}{l}\text { Tiergarten Schönbrunn, } \\
\text { Vienna, Austria }\end{array}$ & NMW 60135 \\
\hline $\begin{array}{l}\text { Hippopotamus } \\
\text { minor }\end{array}$ & $"$ & juvenile & $\begin{array}{l}\text { Late Pleistocene; } \\
\text { Kissonerga, Cyprus }\end{array}$ & CKS 110/B \\
\hline " & $"$ & juvenile & " & CKS 122/B \\
\hline " & $"$ & subadult & " & CKS 117 \\
\hline $\begin{array}{l}\text { Paraceratherium } \\
\text { sp. }\end{array}$ & Rib & adult & $\begin{array}{l}\text { Late Oligocene; } \\
\text { Gözükizilli, Turkey }\end{array}$ & MTA-TTM 2006-1209 \\
\hline$"$ & Tibia & adult & " & CKS 215 \\
\hline Deinogalerix sp. & Femur & adult & $\begin{array}{l}\text { Late Miocene; Gervasio } \\
\text { 1, Gargano, Italy }\end{array}$ & RGM.178017 \\
\hline$"$ & Humerus & adult & $\begin{array}{l}\text { Late Miocene; Chiro } \\
\text { 20E, Foggia, Gargano, } \\
\text { Italy }\end{array}$ & RGM.425360 \\
\hline
\end{tabular}

3 Institutional Abbreviations: CKS Cyprus Kissonerga collection of the University of Athens;

4 MTA Natural History Museum, The General Directorate of Mineral Research and Exploration,

5 Ankara, Turkey; NMB Naturhistorisches Museum Basel, Switzerland; NMING National

6 Museum of Ireland - Natural History; NMW Naturhistorisches Museum Wien, Austria; OMNH

7 Osaka Museum of Natural History, Japan; PIMUZ Paläontologisches Institut und Museum,

8 Universität Zürich, Switzerland; RGM Rijksmuseum voor Geologie en Mineralogie (now

9 Netherlands Centre for Biodiversity Leiden) 


\section{1}

Figure 1: Typical mammalian bone tissue as observed in large mammals such as cervids.

Red bars indicate area and plane of sectioning. Histological images B), E), and I) in linear polarised light, C) in crossed polarised light and with additional use of lambda compensator, and F) in crossed polarised light. A) Life reconstruction of the cervid Megaloceros giganteus ("Knight Megaloceros" by Charles R. Knight, courtesy of the American Museum of Natural History via Wikimedia Commons - http://commons.wikimedia.org). B, C) Bone cortex of an adult tibia of Megaloceros giganteus specimen NMING:F21306/14 displaying an endosteal lamellar layer (innermost part of the cortex) and reticular as well as plexiform fibrolamellar primary bone with growth marks. Note that the primary bone is pervaded by secondary Haversian systems in the inner third of the bone cortex. White arrows indicate lines of arrested growth. Occurrence of LAGs indicated by black/white arrows and the outer circumferential layer (OCL) by white brackets. D) Photograph of Pudu puda ("Pudupuda hem 8 FdoVidal Villarr 08Abr06-Photojimenez", courtesy of Jaime E. Jimenez via Wikimedia Commons - http://commons.wikimedia.org). E, F) Bone cortex of an adult femur of Pudu puda specimen NMW 60135 displaying an endosteal lamellar layer and mainly plexiform fibrolamellar bone. G) Reconstruction of Paraceratherium ("Indricotherium11", Courtesy of Dmitry Bogdanov via Wikimedia Commons - http://commons. wikimedia.org). H) Cross-section of a rib of Paraceratherium sp. specimen MTA-TTM 2006-1209. Red rectangle indicates area of dense Haversian bone magnified in I). 
A

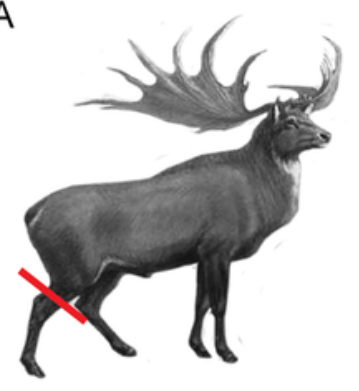

D

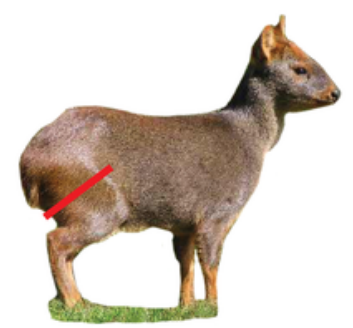

G

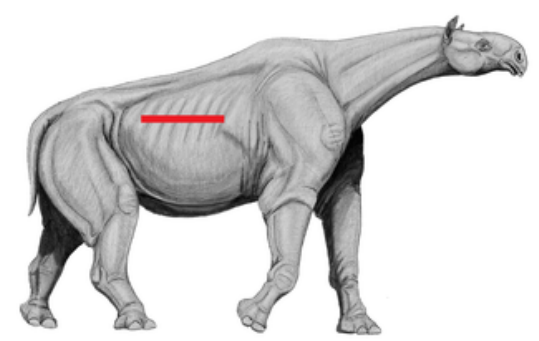

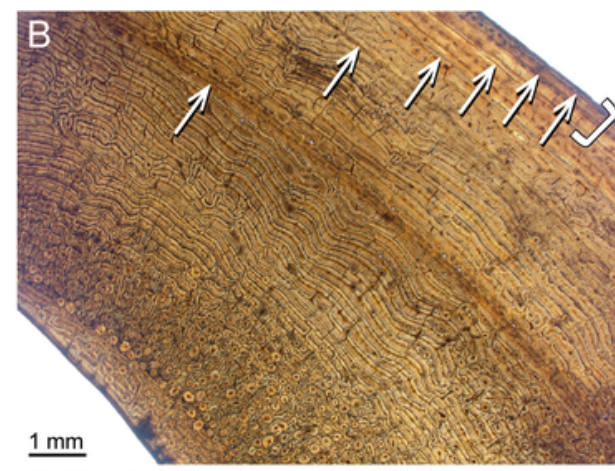
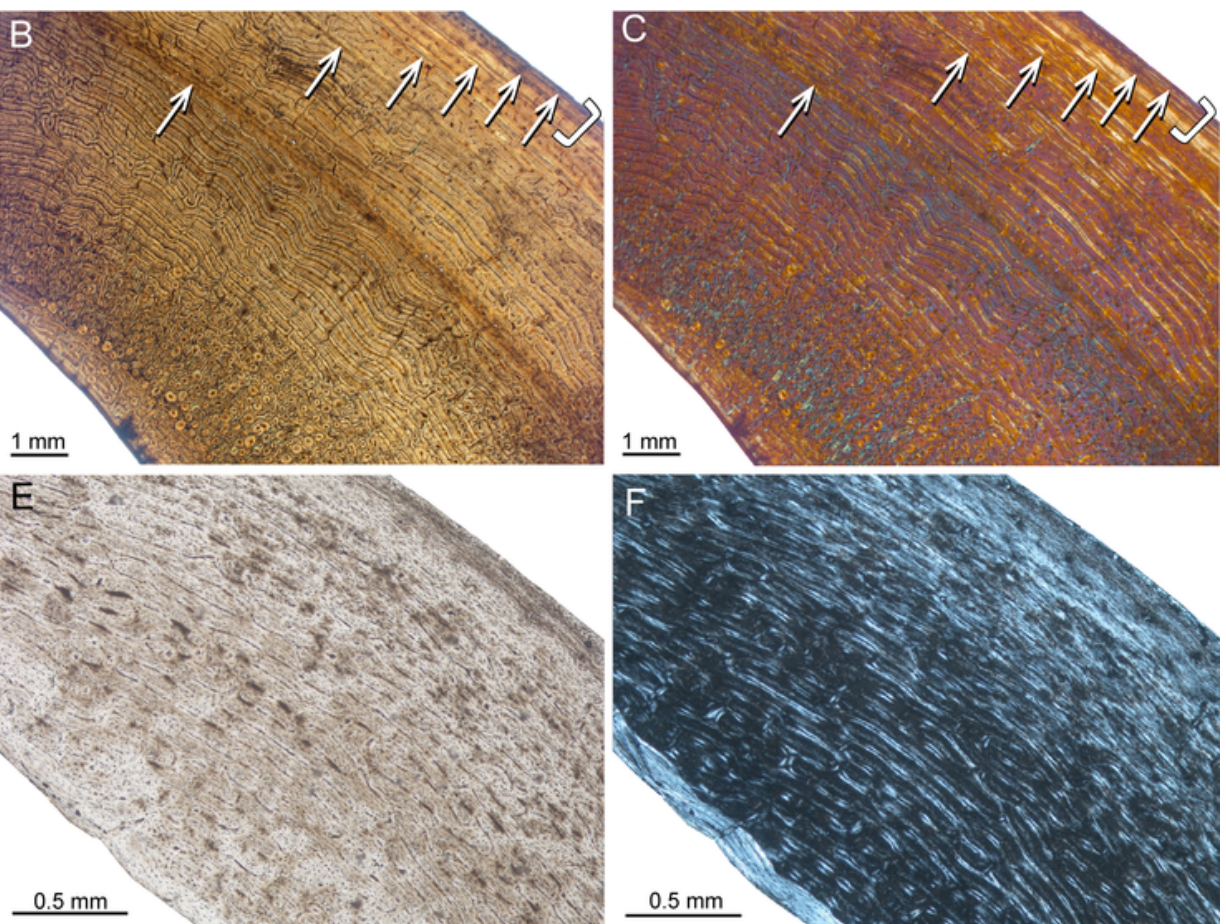

$\mathrm{H}$

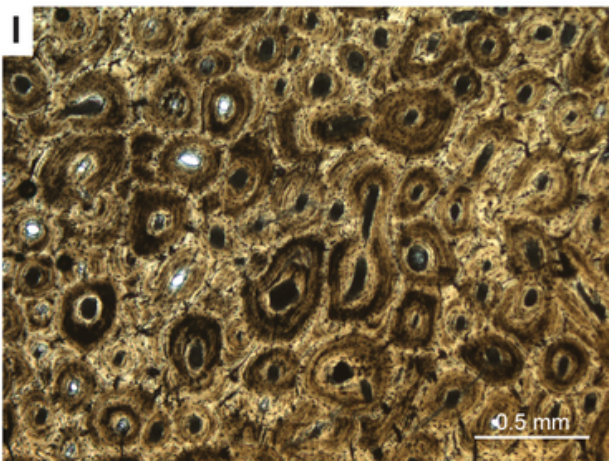


2

Figure 2: Phylogeny of Cynodontia focussing on groups discussed, based on Luo et al. (2005), Luo et al. (2011), Meredith et al. (2011), and O'Leary et al. (2013). Notoungulates and Pantodonta are not included given their controversial systematic position. 


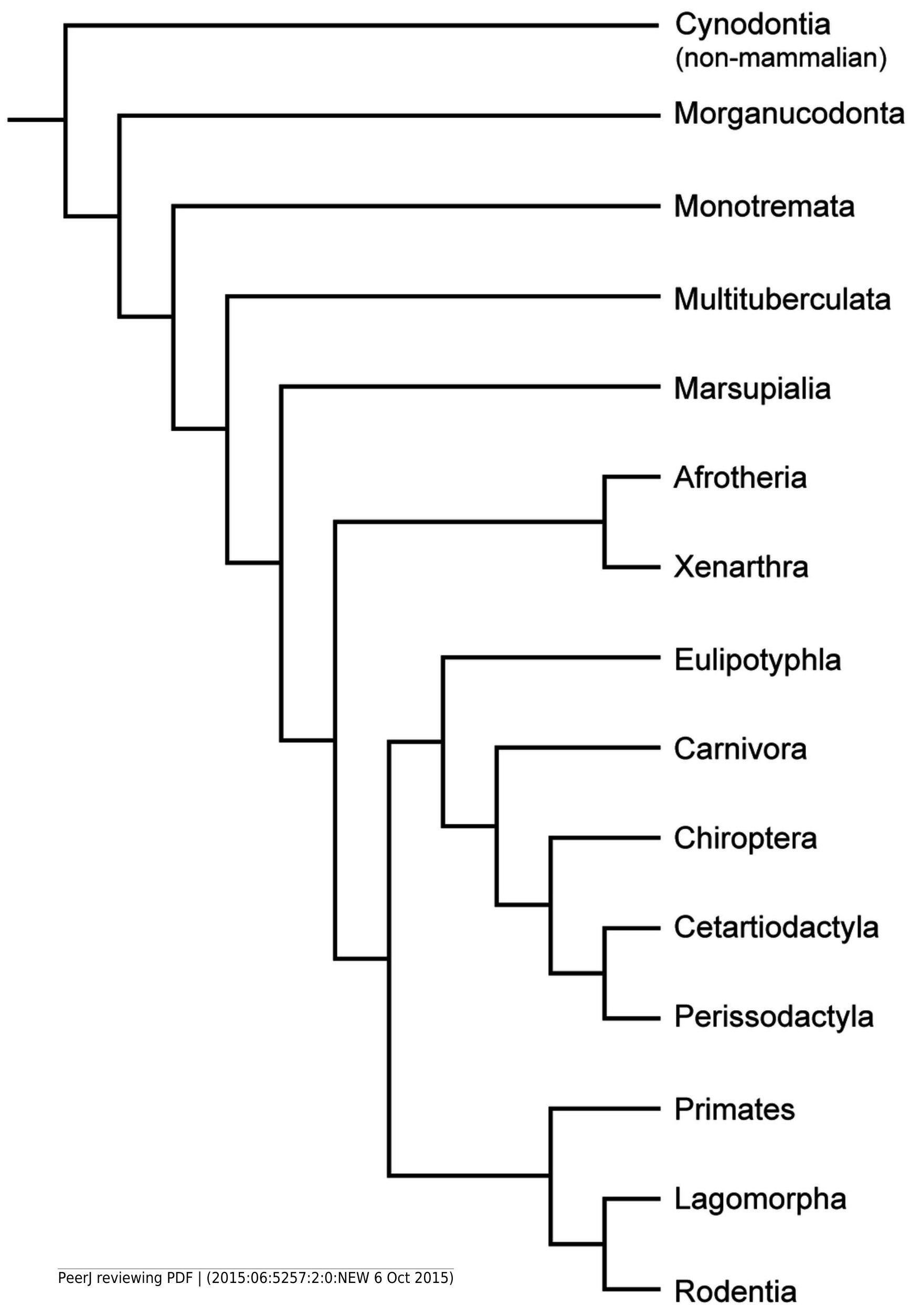




\section{3}

Figure 3: Femoral bone cortex of marsupials.

Histological images A) and D) in linear polarised light and B), C), E), and F) in crossed polarised light. A, B) Outer bone cortex of adult Didelphis albiventris specimen PIMUZ A/V 5279. Note the occurrence of simple primary longitudinal vascular canals and primary osteons in mainly parallel-fibred bone tissue. C) Inner bone cortex of the same specimen displaying a distinct endosteal lamellar layer. D, E) Bone cortex of adult Lutreolina crassicautada specimen PIMUZ A/V 5275. F) Inner cortex of same specimen. Note the occurrence of primary longitudinal vascular canals and primary osteons as well as Haversian systems within the parallel-fibred bone.
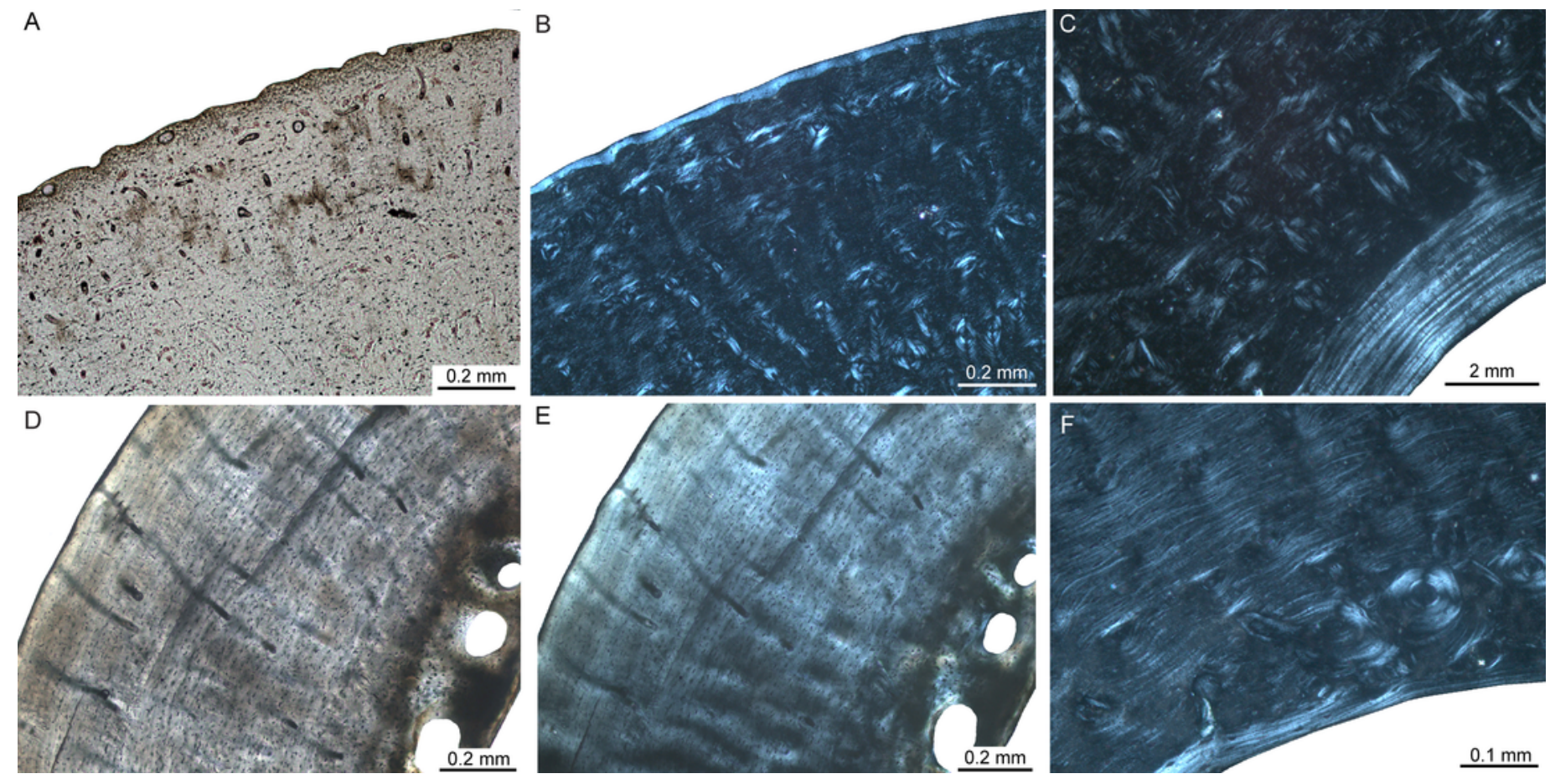
4

Figure 4: Histological features of the femur of Deinogalerix sp.

A) Life reconstruction of Deinogalerix koenigswaldi in comparison to the extant hedgehog Erinaceus (modified from Agustí \& Antón, 2002). B) Adult right femur (specimen RGM.178017) in anterior view. Red bar indicates area and plane of sectioning. C) Lateral bone cortex in crossed polarised light showing parallel-fibred bone and 5 LAGs. Occurrence of LAGs indicated by white arrows.

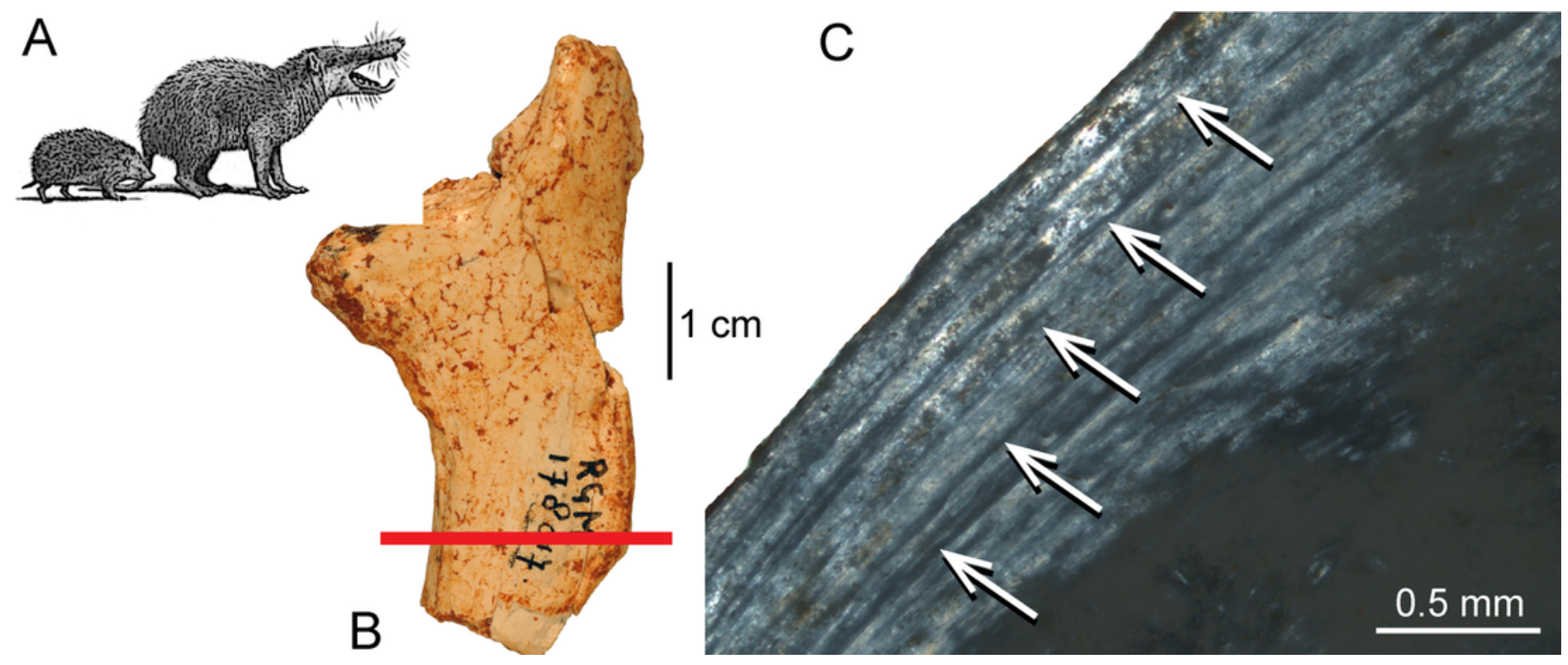




\section{5}

Figure 5: Bone cortex of Hippopotamus minor femora.

A) Life reconstruction (from van der Geer et al., 2010; drawing: Alexis Vlachos) of another Mediterranean dwarf hippopotamid from the Middle Pleistocene of Crete. Since no life reconstruction of Hippopotamus minor is available, we here show the one of Hippopotamus creutzburgi. Histological images B), and C) in linear polarised light, D) in crossed polarised light. B) Small juvenile specimen CKS 110/B. C) Intermediate sized juvenile specimen CKS 122/B showing reticular to plexiform vascularised bone. Note that the middle part mainly consists of reticular bone. D) Outer bone cortex of large juvenile specimen CKS 117 showing mainly parallel-fibred bone. Black and grey areas indicate zones of recrystallisation due to diagenetic alteration of bone tissue. 

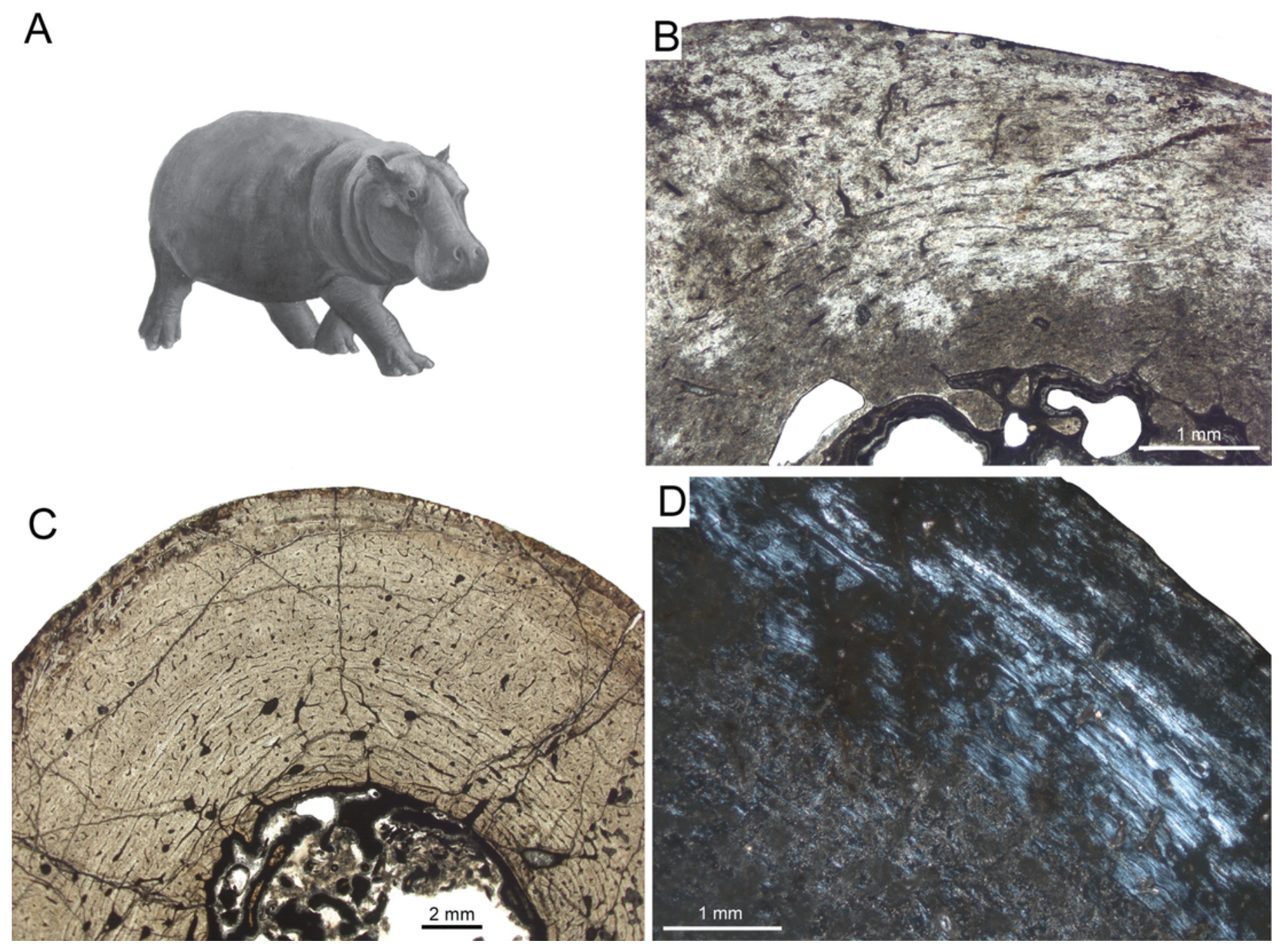
6

Figure 6: Histological features of Sinomegaceros yabei, the megacerine deer from the Pleistocene of Japan.

Histological images in linear polarised light of an adult femur (OMNH QV-4062) depicting A) the whole cross-section and B) a close-up of the outer cortex. The red bar in A) localizes the approximated position of the section on the life reconstruction (courtesy of Hirokazu Tokugawa), and the red rectangle indicates the area of the close-up. B) Note that seven LAGs are visible, as indicated by white arrows. 


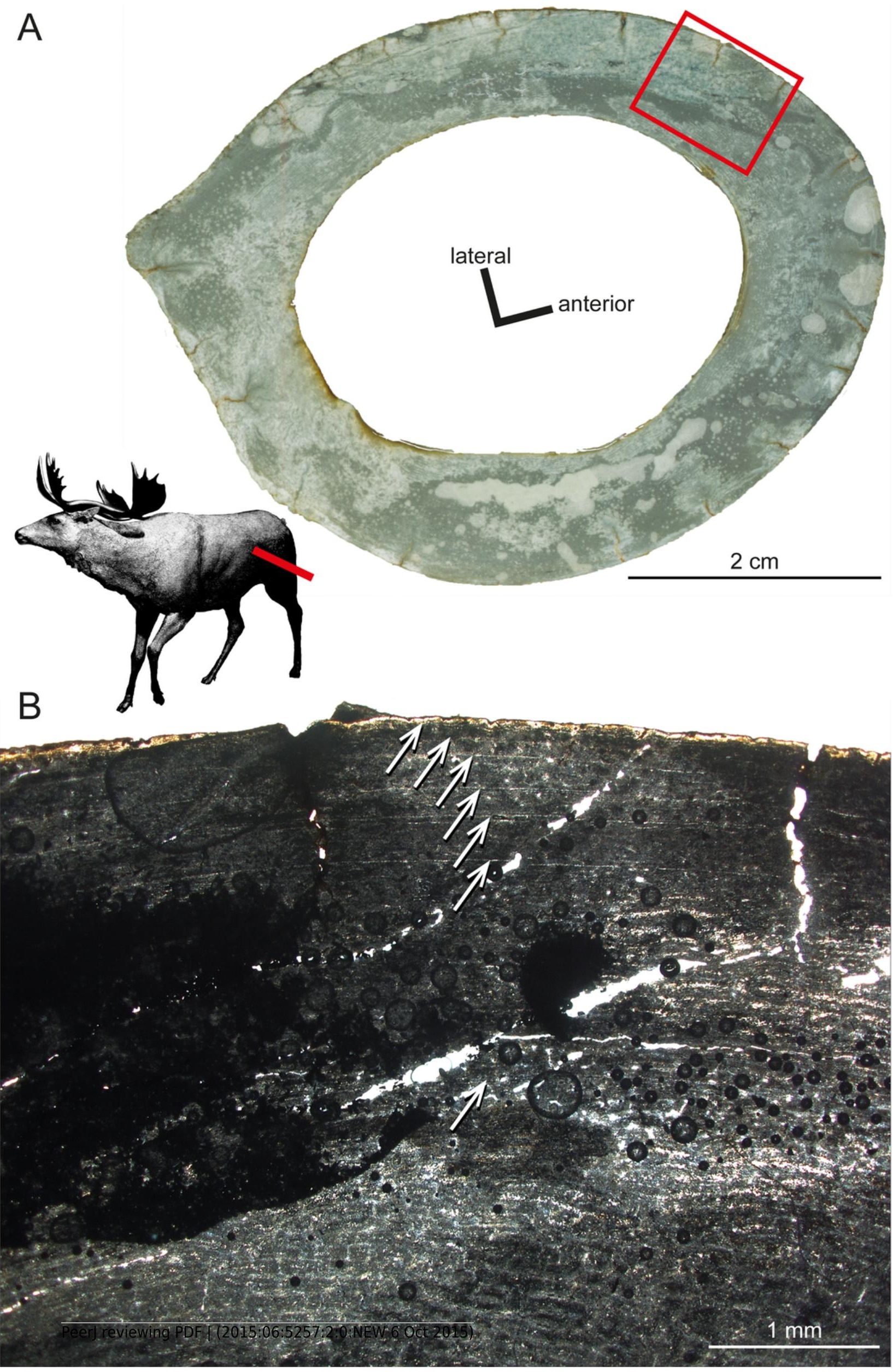




\section{7}

Figure 7: Bone histology of fossil island rodents.

Histological images A) and D) in linear polarised light, B) and E) in crossed polarised light, and $\mathrm{C}$ ) and $\mathrm{F}$ ) in crossed polarised light with additional use of lambda compensator. A-C) Adult Mikrotia sp. femur (specimen RGM.792085) showing disorganised, mainly parallelfibred/lamellar bone in its centre. D-F) Adult femur of Leithia sp. specimen NMB G 2160 displaying a mainly compacted coarse cancellous cortex of endosteal lamellar bone with areas of trabecular infilling and remodelling. Please note that periosteal lamellar bone is only present close to the bone surface.
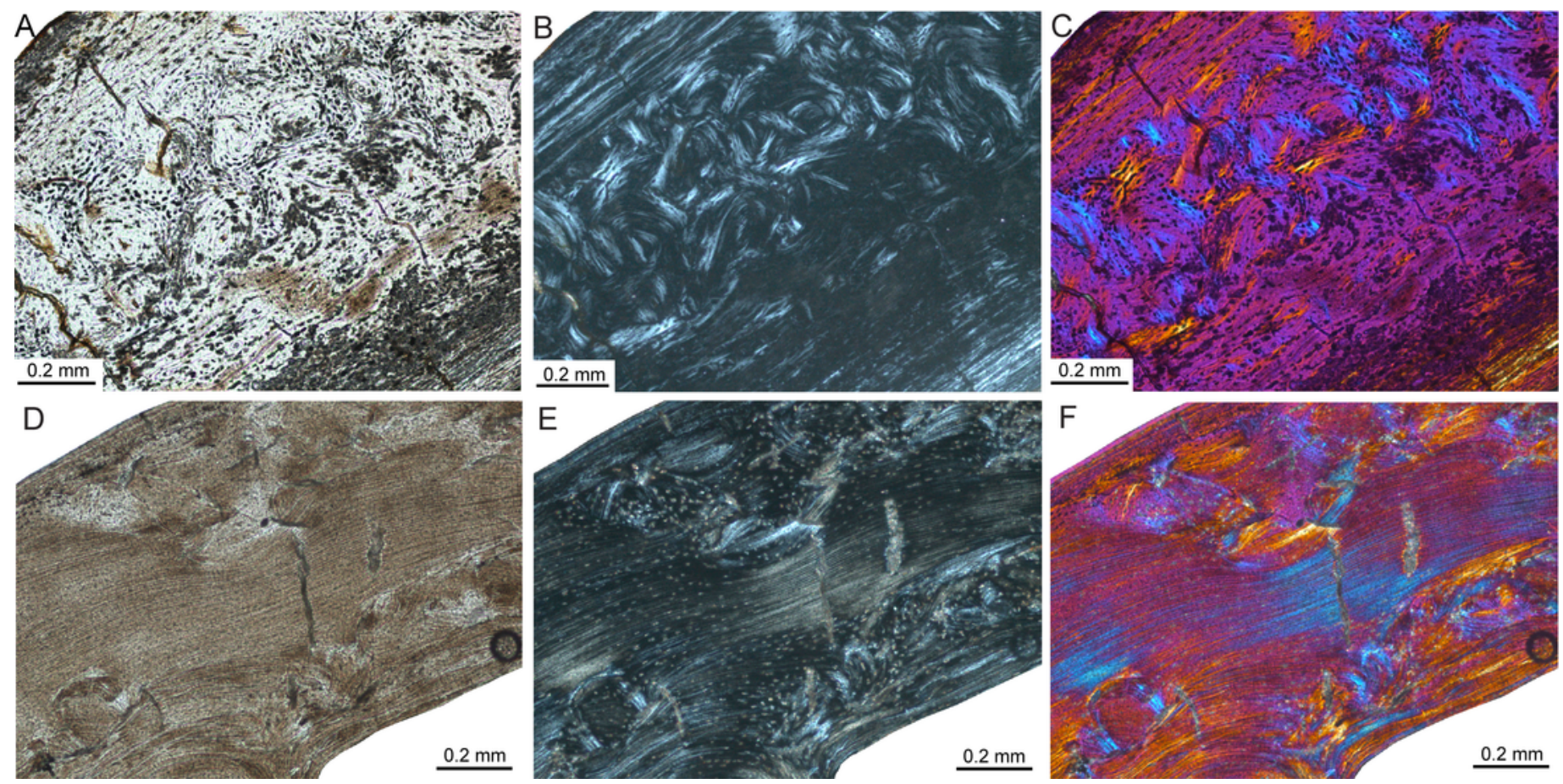


\section{8}

Figure 8: Bone histology of fossil ochotonids.

A) Life reconstruction of Prolagus sardus ("Prolagus3", courtesy of Wikimedia Commons http:/(commons. wikimedia.org ). Histological images B), D), F) in linear polarised light, C) in crossed polarised light with additional use of lambda compensator, and $\mathrm{E}$ ) in crossed polarised light. B, C) Lateral cortex of adult Prolagus oeningensis femur PIMUZ A/V 4532 showing fibrolamellar bone partially pervaded by irregular secondary osteons in the inner part and mainly parallel-fibred bone in the middle and outer part as well as three LAGs. D) Lateral cortex of adult Prolagus imperialis femur RGM.792096 displaying an identical pattern of bone tissue but five LAGs. E) Posteromedial cortex of juvenile Prolagus sardus femur NMB Ty. 4974 showing an area of fibrolamellar bone with a high amount of woven-fibred bone in the inner part and an increasing amount of parallel-fibred bone in the middle and outer part of the cortex. F) Outer anterolateral cortex of adult Prolagus sardus femur NMB Ty.12659 displaying five LAGs. Note that the line in the lower third of the cortex is a resorption line (RL) and not a LAG. Occurrence of LAGs indicated by white or yellow arrows.

A
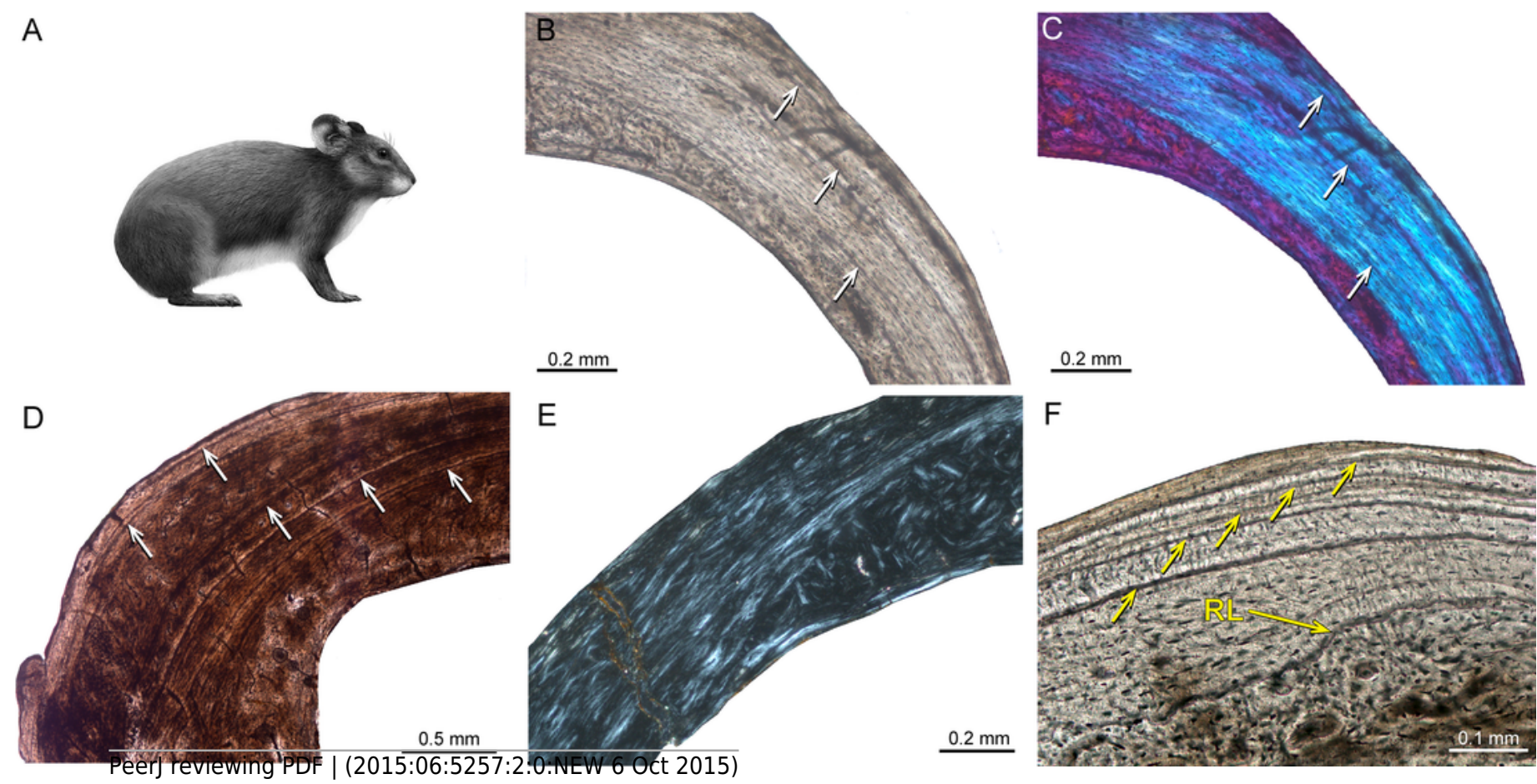

F

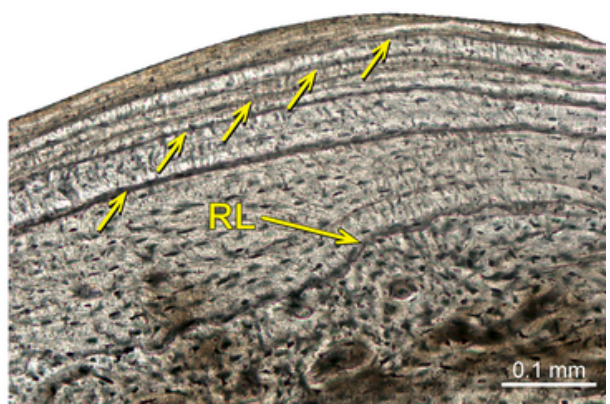




\section{Table 2 (on next page)}

Table 2: Summary of histological traits of non-mammalian cynodonts and major mammalian clades

(based on material sampled and references cited in the current study). The terminology follows Francillon-Vieillot et al. (1990). 
1 Table 2: Summary of histological traits of non-mammalian cynodonts and major mammalian clades (based on material sampled

2 and references cited in the current study). The terminology follows Francillon-Vieillot et al. (1990).

\begin{tabular}{|c|c|c|c|c|c|c|c|c|}
\hline $\begin{array}{l}\text { Histological } \\
\text { traits }\end{array}$ & \begin{tabular}{|l|} 
Non- \\
mammalian \\
cynodonts
\end{tabular} & $\begin{array}{l}\text { Multitubercula- } \\
\text { ta and early } \\
\text { mammals }\end{array}$ & Monotremata & Marsupialia & $\begin{array}{l}\text { Euarchontogli- } \\
\text { res }\end{array}$ & Laurasiatheria & Afrotheria & Xenarthra \\
\hline $\begin{array}{l}\text { Main primary } \\
\text { bone tissue } \\
\text { types }\end{array}$ & $\begin{array}{l}\text { fibrolamellar, } \\
\text { parallel-fibred, } \\
\text { lamellar }\end{array}$ & $\begin{array}{l}\text { fibrolamellar, } \\
\text { parallel-fibred, } \\
\text { lamellar }\end{array}$ & $\begin{array}{l}\text { fibrolamellar, } \\
\text { lamellar }\end{array}$ & $\begin{array}{l}\text { fibrolamellar, } \\
\text { parallel-fibred, } \\
\text { lamellar }\end{array}$ & \begin{tabular}{|l} 
lamellar or \\
parallel-fibred
\end{tabular} & fibrolamellar & fibrolamellar & fibrolamellar \\
\hline $\begin{array}{l}\text { Main } \\
\text { vascularisation } \\
\text { patterns }\end{array}$ & $\begin{array}{l}\text { plexiform, } \\
\text { laminar, } \\
\text { longitudinal, } \\
\text { reticular, radial }\end{array}$ & \begin{tabular}{|l|} 
longitudinal, \\
radial, reticular
\end{tabular} & $\begin{array}{l}\text { longitudinal, } \\
\text { radial, reticular, } \\
\text { laminar }\end{array}$ & $\begin{array}{l}\text { longitudinal, } \\
\text { radial }\end{array}$ & $\begin{array}{l}\text { longitudinal, } \\
\text { reticular, radial }\end{array}$ & $\begin{array}{l}\text { longitudinal, } \\
\text { reticular, radial, } \\
\text { laminar, } \\
\text { plexiform }\end{array}$ & $\begin{array}{l}\text { circumferential, } \\
\text { longitudinal, } \\
\text { reticular, } \\
\text { laminar, } \\
\text { plexiform }\end{array}$ & $\begin{array}{l}\text { longitudinal, } \\
\text { reticular, radial }\end{array}$ \\
\hline $\begin{array}{l}\text { Lines of } \\
\text { arrested growth }\end{array}$ & present & present & $\begin{array}{l}\text { not } \\
\text { documented }\end{array}$ & present & present & present & present & present \\
\hline Remodelling & Haversian bone & not documented & Haversian bone & Haversian bone & Haversian bone & Haversian bone & Haversian bone & Haversian bone \\
\hline
\end{tabular}

